\title{
ELECTROPHORESIS
}

\section{Contactless conductivity detection for analytical techniques \\ - Developments from 2014 to 2016}

\begin{tabular}{|r|l|}
\hline Journal: & ELECTROPHORESIS \\
\hline Manuscript ID & elps.201600280.R1 \\
\hline Wiley - Manuscript type: & Review \\
\hline Date Submitted by the Author: & 05-Aug-2016 \\
\hline Complete List of Authors: & $\begin{array}{l}\text { Kuban, Pavel; Inst. Anal. Chem. AS CR, Electromigration Methods } \\
\text { Hauser, Peter; The University of Basel, Department of Chemistry }\end{array}$ \\
\hline Keywords: & $\begin{array}{l}\text { capacitively coupled contactless conductivity detection, capillary } \\
\text { electrophoresis, microchip electrophoresis, review }\end{array}$ \\
\hline
\end{tabular}

SCHOLARONE $^{m}$

Manuscripts 


\title{
Review
}

\section{Contactless conductivity detection for analytical techniques - Developments from 2014 to 2016}

\author{
Pavel Kubán̆ ${ }^{1}$ and Peter C. Hauser ${ }^{2 *}$ \\ ${ }^{1}$ Institute of Analytical Chemistry of the Czech Academy of Sciences, v.v.i., Veveři 97, CZ- \\ 60200 Brno, Czech Republic \\ ${ }^{2}$ Department of Chemistry, University of Basel, Spitalstrasse 51, CH-4056 Basel, Switzerland
}

Correspondence: Peter C. Hauser, Department of Chemistry, University of Basel, Spitalstrasse 51, CH-4056 Basel, Switzerland, e-mail: peter.hauser@unibas.ch

Keywords: capacitively coupled contactless conductivity detection, capillary electrophoresis, microchip electrophoresis, review
Abbreviations:
DOI - dual opposite end injection
EME - electromembrane extraction
FIA - flow injection analysis
FS-PCF - fused silica photonic crystal fiber 
GEMBE - gradient elution moving boundary electrophoresis

IC - ion chromatography

ITO - indium tin oxide

LAMP - loop-mediated isothermal amplification

MCE - microchip electrophoresis

$\mu$-EME - micro-electromembrane extraction

OT - open tubular

PEEK - polyether ether ketone

PIM - polymer inclusion membrane

RCA - rolling circle amplification

SIA - sequential injection analysis

SLM - supported liquid membrane

SPE - solid phase extraction 


\section{Introduction}

This article is the latest update of a series of reviews on capacitively coupled contactless conductivity detection $\left(C^{4} D\right)$ written by the authors for this journal since 2009 [1-4]. $C^{4} D$ in the present form was introduced in $1998[5,6]$ and different aspects of the topic have been reviewed by different authors since: by Zemann in 2001 and 2003 [7, 8], by Guijt et al. in 2004 [9], by Šolínová and Kašička in 2006 [10], by Pumera in 2007 (with a focus on microchip devices) [11], by Matysik in 2008 [12], by Trojanowicz in 2009 (in the broader context of detection in flow analysis) [13], by Mark et al. in 2012 (electrochemical detection methods in capillary electrophoresis) [14], by Coltro et al. in 2012 (microchip and microfluidic devices) [15], and by Elbashir and Aboul-Enein in 2010, 2012 and 2014 (pharmaceutical and related applications) [16-18].

About 100 publications on $C^{4} D$ have appeared from June 2014 to April 2016, the approximate period covered by this review. This matches the numbers seen in the previous reviews prepared for the 2 year periods from 2012 - 2014 [1] and 2010 - 2012 [2].

The first part of the present review covers the more fundamental aspects, while the second part is concerned with applications of CE-C ${ }^{4} \mathrm{D}$ implemented with conventional capillaries and on microchip devices as well as new applications of $\mathrm{C}^{4} \mathrm{D}$ other than in $\mathrm{CE}$. Note that individual publications are sometimes referred to repeatedly in different contexts. Tables provide summaries of applications with some detail on experimental conditions. As always, we strove to include all relevant publications and apologize if we should have missed any important reports. 


\section{Fundamental characterization and modified detector designs}

\subsection{Conventional capillaries}

Dasgupta and coworkers carried out a detailed study of the characteristics of $C^{4} D$ for conditions not previously investigated, i.e. with a special focus on very narrow capillary diameters (down to $\sim 1 \mu \mathrm{m}$ ) and electrolyte concentrations much lower than usually encountered in CZE $[19,20]$, as they were mainly interested in detection in open tubular ion chromatography (OT IC) [21]. Both factors lead to very high resistance values for the cell. Please note, that resistance is simply the inverse of conductance. They found that $\mathrm{C}^{4} \mathrm{D}$ also works well for these more challenging than usual conditions, but that its frequency characteristics and the effects of solution conductivity and geometry of the cell could only be predicted satisfactorily with an extended model consisting of a large number of distributed resistors and capacitors similar to the one originally proposed by da Silva and do Lago [6]. A sketch of their cell and its representation is shown in Fig. 1. For standard CE conditions a simple equivalent circuitry (a lumped element model) consisting of a serial arrangement of capacitor/resistor/capacitor is generally adequate [22]. The model by Dasgupta and coworkers also includes solution capacitances in parallel to the solution resistance, which previously had largely been neglected. The extensive study showed that for the high resistance cells, capacitive effects were dominating at high frequencies and relatively low frequencies were required for best sensitivity. This confirmed an effect noted earlier by the authors of the present review which was not understood at the time [23]. Consequently, the detector developed by Dasgupta and coworkers was operated at surprisingly low frequencies of 500 $\mathrm{Hz}$ for OT IC and of $1-12.3 \mathrm{kHz}$ for CE [20]. A CE-C $\mathrm{C}^{4}$ separation of inorganic anions in two narrow bore capillaries is depicted in Fig. 2. Under the resulting high resistance conditions investigated a significant part of the cell response might be due to changes of the solution capacitance on variation of the electrolyte concentration (due to the effect on the 
dielectric constant). This prompted the authors also to discuss the nomenclature for $\mathrm{C}^{4} \mathrm{D}$. The use of 'admittance detector' is suggested, admittance being the more general term for the ease of which a circuitry allows a current flow, which accounts also for capacitive and inductive circuit elements. As a $\mathrm{C}^{4} \mathrm{D}$-cell is, of course, not just a resistor, strictly speaking this term is always correct. On the other hand, the term conductivity detection denotes the parameter usually intended to be measured. Except for extreme conditions, such as high resistance cells, where this might not be possible, operating conditions are usually optimized to suppress the influence of the capacitive elements. These are also not necessarily variable in a series of measurements, so that the response in practice usually follows changes in the resistive term only. Readers specifically interested in the fundamental aspects of $\mathrm{C}^{4} \mathrm{D}$ may also wish to consult earlier studies reported by Opekar et al. [24], Jorgenson and coworkers [25], do Lago and coworkers [26, 27], or publications from our group [22, 28-30].

Drevinskas and coworkers [31, 32] as well as Elkin [33] designed detectors based on integrated circuits available from Analog Devices for the high resolution measurements of small capacitance changes (AD7745 and AD7746). These devices are intended for the measurement of signals from sensors, such as for pressure and humidity, and incorporate all the necessary circuitry including an analog-to-digital convertor in a tiny surface mount package. It had previously been reported that such integrated circuits may be employed to acquire signals from $\mathrm{C}^{4} \mathrm{D}$ cells even though the devices are designed for capacitance, not resistance, measurements [34]. Presumably, the response obtained by the authors for the standard CZE conditions is not due to the effect of the electrolyte concentration on solution capacitance as discussed by Dasgupta for the high resistance cell (see preceding paragraph). But as also Dasgupta has pointed out [19], this must be due to the fact that the integrated devices are meant to measure isolated capacitors, not circuitries consisting of several 
components, and thus produces a varying error signal when a changing resistive element is present (see the data sheet for the device). Nevertheless, the approach allows the construction of very compact detectors based on just a single integrated circuit, with good performance $[31-33]$

Zheng et al. [35] investigated the performance of a $\mathrm{C}^{4} \mathrm{D}$-cell based on 3 active electrodes arranged axially. The centre electrode was used for signal pick-up, while the two outer electrodes were used for excitation with a sine wave. This was applied to the two electrodes with a phase shift of $170^{\circ}$ and led to an increase in the sensitivity for peaks by about $20 \%$ compared to the normal 2-electrode configuration. Trinh and coworkers [36] described the opposite arrangement, i.e. the centre one of three electrodes was used for excitation and the two outer ones for picking up the signal. These were connected to grounded resistors and a difference amplifier was employed to monitor the voltage differential. The cell was employed for the monitoring of bubbles and particles in a fluidic stream.

Ji et al. [37] reported an update on a $C^{4} \mathrm{D}$-system incorporating an inductor arranged in series with the measuring cell. This allows the measurement at relatively low frequencies, at which otherwise the coupling capacitances would be limiting the current through the cell. For a discussion of this approach see the previous review in this series [1]. The new detector described by Ji et al. for pipes in the millimeter scale includes two inductors instead of the single one of the previous design [38]. It is stated that this improves the response to solutions of low conductivity. The inductances required in this approach are relatively large, requiring bulky coils. For this reason the authors also investigated the use of a so-called simulated inductor [39]. This consists of an active circuitry, incorporating several operational amplifiers, which behaves like a large inductor and thus can be used as a substitute. It was shown that for 
a given cell at the relatively low operation frequency of about $150 \mathrm{kHz}$ the signal could be improved compared to the standard arrangement without the simulated inductor. The full frequency characteristics were not studied.

$\mathrm{C}^{4} \mathrm{D}$-systems can be constructed from electronic components readily available from distributors and with limited mechanical effort. These can perform very well if attention is paid to the characteristics of the cell and the excitation and pick-up sections are efficiently shielded from each other to minimize stray capacitance and thus limit the background signal. It is also essential to include an operational amplifier on the pick-up side directly in the cell. Da Costa et al. [40], in an article on a trend to build laboratory hardware in an open source community approach, included the demonstration of $\mathrm{C}^{4} \mathrm{D}$ (for endpoint determination in titrations). Details on the construction of their $C^{4}$ D-system are shared on a web-site [41].

\subsection{Microchip electrophoresis}

The interest in the development of $\mathrm{C}^{4} \mathrm{D}$ cells for microchip electrophoresis devices has mainly focussed on alternative electrode materials. Yan et al. [42] reported the use of electrodes made from indium tin oxide (ITO) in microchip electrophoresis. This conducting material is normally used when transparent electrodes are required. However, this was not a requirement for their cell design, and the benefit of the approach compared to normal metallic electrodes is not clear. Chagas et al. described the use of electrodes drawn by hand with pencils onto paper [43]. The electrode plates were fabricated as separate sheets, which were bonded with standard PMMA microchips. This resulted in an extremely cheap (less than 1 cent) and simple (only paper and pencil was required) protocol for fabrication of the electrodes, which were produced with the precision of batch-wise etching procedures. 
The distance of the sensing electrodes from the separation channel is critical for MCE-C ${ }^{4} \mathrm{D}$ sensitivity [44]. In previous microchip designs, metallic $C^{4} D$ electrodes were usually embedded into the microchannel structure and were covered by a thin layer of insulating material for good transmission of the a. c. signal from the function generator into the separation channel and from the separation channel into the current-to-voltage processing circuitry. Coltro and coworkers [45] demonstrated that the material for $\mathrm{C}^{4} \mathrm{D}$ electrodes can be formed by conductive solutions embedded directly underneath the separation microchannel. Two electrode channels $(1 \times 1 \mathrm{~mm})$ were engraved in a PMMA substrate, sealed with a thin adhesive membrane $(40 \mu \mathrm{m})$ and bonded with a lithographically fabricated PDMS microchip. The electrode channels were subsequently filled with various solutions of salts (2 $\mathrm{M} \mathrm{KCl}$ was chosen as optimum "electrode material") and transmitted the excitation/pick-up a. c. signals in the same way as standard metal electrodes.

\section{Instrumental developments}

\subsection{Portable and purpose made benchtop CE-C ${ }^{4} D$-instruments}

Because of its inherent simplicity, CE lends itself well to the in-house construction of instruments tailored to specific applications. Portable analytical devices play a key role in applications where immediate information on sample composition is required on-site. This may, for example, be necessary in environmental, clinical and toxicological analyses, food quality control, point-of-care patient testing, chemical warfare detection and many other analytical areas. $\mathrm{CE}$ with $\mathrm{C}^{4} \mathrm{D}$ is well suited for portable applications since the instrumentation is simple and has low power requirements. This has even inspired the open source hardware 'hacker' community and a project on a home-built CE-C ${ }^{4} \mathrm{D}$ instrument was one of the semi-finalists in the Hackaday competition in 2015 [46]. Most portable CE 
instruments reported in the literature make use of $\mathrm{C}^{4} \mathrm{D}$. Reviews on portable $\mathrm{CE}$ instruments have appeared in 2010 [47], 2013 [48] and most recently in 2016 [49].

Various portable instruments for CE-C ${ }^{4} \mathrm{D}$ were presented during the last two years. Early inhouse constructed instruments usually relied on electrokinetic or improvised manual hydrodynamic injection such as siphoning, but more often now partly automated instruments are reported. Cylinders with a compressed gas were employed for liquid handling in portable CE- $\mathrm{C}^{4} \mathrm{D}$ instruments. Nguyen and coworkers reported a simple instrument which featured automated pressure driven flushing of the capillary, but relied on manual siphoning for sample injection [50, 51]. Duong et al. presented an investigation on the use of such in-house built instruments for field applications in Vietnam [52].

$\mathrm{C}^{4} \mathrm{D}$ has the great benefit of universality, but on the other hand different classes of analytes often require different separation conditions. As the instrumentation is simple, it is readily possible to duplicate the separation system even for portable CE-C $\mathrm{D}^{4}$ instruments. Sáiz et al. reported a system with two distinct channels for concurrent separations of inorganic anions and cations in fireworks [53]. This system was pneumatically driven and employed an engraved microfluidic manifold in order to keep the set-up simple and compact. Mai et al. extended this approach to a portable system with three channels suitable for delivery of individual BGE solutions into each channel, which enabled the simultaneous determination of inorganic cations, as well as of fast inorganic and slow organic anions [54].

Gorbatsova et al. reported a portable CE-C ${ }^{4} \mathrm{D}$ instrument which employed a digital microfluidic platform to deliver droplet sized samples to the capillary inlet and piezoelectric micropumps for hydrodynamic injection [55]. A small and compact portable CE-C ${ }^{4} \mathrm{D}$ for on- 
site analyses of small volumes of human body fluids was developed by Greguš et al. [56]. This instrument employed automated siphoning injection. The size and weight of the entire instrument, including a tablet computer for data acquisition, was $33 \times 20 \times 17 \mathrm{~cm}$ and less than $5 \mathrm{~kg}$, respectively, and allowed for repeated injections from sample volumes as low as 10 $\mu \mathrm{L}$. A photograph of the portable $\mathrm{CE}-\mathrm{C}^{4} \mathrm{D}$ instrument and its application for the determination of formate in serum of methanol intoxicated patients are shown in Fig. 3.

Purpose made bench-top instruments incorporating $\mathrm{C}^{4} \mathrm{D}$ have also been reported. Automation of liquid handling was obtained through standard SIA and FIA manifolds using peristaltic [57], linear [58] or piezoelectric micropumps [59,60], which were directly connected to flowthrough interfaces for BGE flushing, sampling and BGE replenishment before CE separation. A stationary $\mathrm{CE}-\mathrm{C}^{4} \mathrm{D}$ system with pneumatically driven liquid handling has also been described [61]. A microfluidic breadboard approach for assembling simple CE, ITP and gradient elution moving boundary electrophoresis (GEMBE) systems from off-the-shelf miniature components, including syringe pumps and valves, was presented by Koenka et al. [62]. A new semi-automated micro-injector for CE- $C^{4} \mathrm{D}$, capable of handling a total sample volume of as little as approximately $300 \mathrm{~nL}$, was reported by Sáiz et al. [63]. Tycova and Foret reported a novel CE-MS system in which $\mathrm{C}^{4} \mathrm{D}$ was employed as an auxiliary to trigger a reduction of the electrophoretic voltage prior to the passage of the ions of interest [64]. This was necessary in order to obtain a stable electrospray at the capillary end as required for the MS-detection.

\subsection{Verification of simulation models for CE-separations}

Thormann and coworkers employed $\mathrm{C}^{4} \mathrm{D}$ for verification of simulations of CE-separations $[65,66] . \mathrm{C}^{4} \mathrm{D}$ is well suited for this approach as the detector signal is based on the same 
property of the ions as their separation, namely electrophoretic mobility, and thus both can be modelled on the same basis. If the simulation can be experimentally verified, it not only improves the theoretical understanding of processes, but it can then also be employed for the prediction of results obtained for further conditions without having to carry out the practical work in the laboratory. Through a combination of modelling and experimental verification, the authors could show that band broadening caused by a superimposed hydrodynamic flow can be neglected for capillaries with diameters $\leq 25 \mu \mathrm{m}$ and is also not significant for capillaries of larger diameters if the flow rates are below certain limits [66]. This finding is deemed important as it implies that pressure assistance may play a more important role in CE. It had indeed been shown by Mai et al. for CE-C ${ }^{4} \mathrm{D}$ in capillaries of 10 and $25 \mu \mathrm{m}$ inner diameter that a superimposed hydrodynamic flow may be employed for various purposes, such as the optimization of separation, analysis time and compensation of EOF in the separation of anions [67-70]. In the second publication by Thormann and coworkers, computer simulations of selected electrophoretic separations were further confirmed by real CZE and ITP measurements using a $C^{4} D$ array consisting of 8 consecutive $C^{4} D$ cells [65]. This allowed the monitoring of transient processes and revealed, for example, for an ITP experiment, that the EOF was not constant during the experiment.

\section{Applications of CE-C ${ }^{4} D$}

\subsection{Electrophoresis methods with conventional capillaries}

Application areas and research topics investigated by $C E-C^{4} \mathrm{D}$ within the last 2 years remained fairly consistent with the topics reviewed for the periods from 2010 to 2012 and 2012 to $2014[1,2] . C^{4} \mathrm{D}$ is mostly employed for small inorganic or organic ions which do not absorb in the UV-range. Due to the simplicity of $\mathrm{C}^{4} \mathrm{D}$ it is sometimes also used for UVabsorbing species, with detection limits approaching those of UV-detectors. CE- $\mathrm{C}^{4} \mathrm{D}$ has 
therefore mostly been applied in the pharmaceutical, clinical, food and environmental analyses of small ionic species. A comprehensive list of $C E-C^{4} D$ applications published from June 2014 to April 2016 is given in Table 1 and additional information on recent applications of CE-C $\mathrm{C}^{4} \mathrm{D}$ in pharmaceutical, biomedical and food analyses can be found in the review article by Elbashir and Aboul-Enein [18].

\subsubsection{Pharmaceutical, clinical and forensic analysis}

Many pharmaceuticals, illicit drugs and other clinically important compounds are small ions and molecules with no or weak chromophores and their determination using CE with optical detection might not be readily possible. On the other hand, most of these compounds are charged in certain $\mathrm{pH}$ ranges and their detection by means of conductivity measurements is feasible. Numerous publications on CE-C ${ }^{4} \mathrm{D}$ determination of pharmaceutically and clinically important compounds were reported in the last two years.

The determination of the active component of ecstasy tablets, 3,4-methylenedioxy- $N$ methylamphetamine, and its counterfeit alternative, meta-chlorophenylpiperazine, was carried out by CE-C $\mathrm{C}^{4} \mathrm{D}$ [71]. The development of new analytical methods for $\mathrm{CE}-\mathrm{C}^{4} \mathrm{D}$ determination of non-steroidal anti-inflammatory drugs [72] and of analgesic and antipyretic drugs [73] in commercial preparations was also reported. The CE- $\mathrm{C}^{4} \mathrm{D}$ determination of various analgesic/antipyretic drugs is depicted in Fig. 4. CE-C ${ }^{4} \mathrm{D}$ systems used for the determination of colistin [57], $\beta$-agonists [50] and amphetamine-type drugs [51] demonstrated the suitability of CE-C $\mathrm{C}^{4} \mathrm{D}$ instrumentation in the analyses of pharmaceutical formulations and illicit drugs.

Determination of pharmaceuticals in tablets and liquid formulations does usually not require a sophisticated analytical protocol since concentrations of target analytes in the samples are 
high and sample matrices are rather simple. Normally, the tablets are ground into fine powder, dissolved and diluted with deionized water and the samples can be directly analysed by CE$\mathrm{C}^{4} \mathrm{D}$ after filtration or centrifugation. Liquid formulations require dilution and filtration/centrifugation steps prior to $\mathrm{CE}-\mathrm{C}^{4} \mathrm{D}$ only. On the other hand, analyses of pharmaceutically relevant compounds in clinical samples are significantly influenced by the sample matrix and sample pretreatment is usually required prior to CE analyses. Sample treatment usually eliminates detrimental effects of sample matrix on CE separations and increases analyte concentrations to detectable levels. This is particularly important for analyses of human body fluids, such as whole blood, serum, plasma, urine and saliva, which are often carried out in clinical assays.

Pretreatment of human body fluids prior to $C E-C^{4} D$ analyses was performed by standard techniques, such as precipitation [74-76] and liquid-liquid extraction [51, 77], moreover, the application of novel microextraction techniques [78-81] was also reported. Determination of formic acid in whole blood and serum samples after methanol intoxication [78], three amphetamines in spiked plasma samples [79], plasma concentrations of branched chain amino acids in secretion studies [74] and tamoxifen and its metabolites in plasma samples of patients with breast cancer undergoing tamoxifen treatment [77] were presented. Urine and plasma samples of patients suffering from diabetes were analysed for the presence of the oral antidiabetic drug metformin [75] and four amphetamines were determined in urine of suspected drug addicted individuals using a portable CE-C ${ }^{4} \mathrm{D}$ system [51]. Rapid simultaneous CE-C $\mathrm{C}^{4} \mathrm{D}$ determination of acidic (ibuprofen) and basic (procaine) drugs after micro-electromembrane extraction of $1.5 \mu \mathrm{L}$ of undiluted urine sample was reported by Kubáň and Boček [81]. 
In analyses of major constituents of human body fluids, the sample pretreatment might be considerably simplified and an approx. 100-fold dilution with deionized water, filtration and direct injection into CE-C ${ }^{4} \mathrm{D}$ might be sufficient. Determination of ammonia and creatinine [58] and of metformin [75] in diluted human urine as well as analyses of formate in diluted human serum $[56,82]$ were reported. Direct injections of exhaled breath condensate (EBC), a recently proposed non-invasively sampled human body fluid, were also shown suitable for CE-C ${ }^{4} \mathrm{D}$. Greguš et al. reported analyses of various inorganic cations/anions and organic anions in EBCs associated with different types of respiratory diseases, such as cystic fibrosis and asthma, with statistically significant variations in content of particular ions in healthy and ill individuals [56, 82, 83]. Dual opposite end injection (DOI) [83] for simultaneous analyses of anions and cations and application of a portable CE-C ${ }^{4} \mathrm{D}$ instrument [56] for on-site analyses were used for rapid determination of the small ions.

Saliva is another human body fluid that is potentially interesting in clinical analysis due to the non-invasive sampling character. Moreover, as the content of proteinaceous matrix components is relatively low, pretreatment of saliva samples is rather simple and usually requires dilution and filtration/centrifugation only. Various major as well as minor analytes were determined in saliva samples demonstrating the potential of CE-C ${ }^{4} \mathrm{D}$ in analysis of salivary inorganic anions [84], $\gamma$-hydroxybutyric acid [76], inorganic cations/anions and organic anions [85] and polyamines [80]. DOI was applied for simultaneous determination of cations and anions to reduce the total analysis time [85] and EME (see Section 3.2) was necessary to preconcentrate salivary polyamines to levels detectable by $\mathrm{C}^{4} \mathrm{D}[80]$.

\begin{abstract}
Analyses of biological materials, other than human body fluids, were also reported in the reviewed period. Contamination of milk samples with melamine was investigated after on-
\end{abstract}


line preconcentration by field amplified sample injection (FASI) [86]. Determination of abnormal concentrations of inorganic cations and anions in sweat and skin wipe samples was used for confirmation of respiratory diseases, such as cystic fibrosis [87]. Rabbit corneas were examined for the presence of polyhexamethylene biguanide and chlorhexidine after application of eye drops containing the drugs [88] and separations of the D,L-serine enantiomers in rat brain tissues were demonstrated [89]. Various other biological materials, such as mussel tissues [90, 91], honey [92], plant extracts [93], bee venom [32] and culture media for the development of embryos [94] were also investigated.

\subsubsection{Food analysis}

Consumption of contaminated or counterfeit food presents a serious problem. Food quality might be reliably controlled by various analytical methods and $C E-C^{4} D$ has been used in the determination of small ionic compounds in different food samples in the reviewed period.

Koenka et al. demonstrated the determination of inorganic impurity cations in a sample of Himalayan rock salt [62]. The determination of small inorganic and organic cations and anions in alcoholic and non-alcoholic beverages was reported by Mai et al. [54]. Their system also could be used for the determination of artificial sweeteners which were determined in soft drinks and fish sauce samples. Three common artificial sweeteners (acesulfame-K, saccharin and cyclamate) were also sensitively determined in beverages by use of stacking (FASI) and CE-C ${ }^{4} \mathrm{D}$ by Yang et al. [95]. Limits of detection (LODs) in the low $\mu \mathrm{g} / \mathrm{L}$ concentrations were reported, which were substantially below their maximum admissible levels [95]. 
Glutamic acid is a non-essential amino acid, which is often used as a taste enhancer (in form of monosodium glutamate) in food samples. A simple and inexpensive CE-C ${ }^{4} \mathrm{D}$ method was developed for direct determination of glutamic acid in soy sauce in the presence of excessive levels of $\mathrm{Na}^{+}$and other amino acids [96]. $\mathrm{C}^{4} \mathrm{D}$ is a universal detection method for all charged species and derivatization was not necessary since glutamic acid was rendered a cationic species at the $\mathrm{CE}-\mathrm{C}^{4} \mathrm{D}$ working conditions (BGE with $\mathrm{pH}$ 2). Virgin olive oil is a frequent ingredient in many cuisines world-wide and the content of inorganic cations and anions is important from the nutritional point of view as well as for geographical classification of the oil. Two CE-C ${ }^{4} \mathrm{D}$ methods for sensitive determination of inorganic cations [97] and anions [98] in virgin olive oils were reported by de Jesus and co-workers.

The determination of certain analytes in food samples which are poorly soluble in aqueous media requires the use of organic solvents, and non-aqueous capillary electrophoresis (NACE) with $\mathrm{C}^{4} \mathrm{D}$ has been further investigated. Tian and Qin reported the concurrent separation of mixtures of inorganic anions and long chain alkyl sulphates in a mixture of dimethylformamide and acetic acid [92]. Wu et al. [99] separated fatty acids from edible oil samples in a partly aqueous medium incorporating $35 \%$ acetonitrile and $15 \%$ propanol and Böckel et al. [100] determined oleic acid in soybean oil in a medium based on a mixture of methanol and propanol. Campos et al. [96] found that the inclusion of acetonitrile in the background electrolyte eliminated a peak-splitting artefact which was otherwise present for glutamic acid.

\subsubsection{Environmental, industrial and other samples}

The analyses of amino acids in soil samples was reported by Gorbatsova et al. [55]. Duong et al. gave an account of the determination of inorganic anions/cations, including the 
determination of toxic As(III) [52] in water samples. Pham et al. reported the monitoring of the nitrogen species ammonium, nitrite and nitrate during a purification run in a denitrification reactor for groundwater contaminated with ammonia [61]. Perchlorate [101], haloacetic acids [102]] and bromate [103] were determined in drinking water samples following sample pretreatment by electromembrane extraction as discussed in the following section. This allowed for the determination of the species at sub- $\mu \mathrm{g} / \mathrm{L}$ to $\mu \mathrm{g} / \mathrm{L}$ concentrations. CE-C ${ }^{4} \mathrm{D}$ of selected haloacetic acids in potable water samples is illustrated in Fig. 5.

Few reports were dedicated to analyses of industrial samples. CE- $\mathrm{C}^{4} \mathrm{D}$ was used for the determination of a powdered biocide (tetrakis(hydroxymethyl)phosphonium sulfate) in commercial formulations and for confirmation of its presence in cooling and tap water samples treated with the biocide by Marques et al. [104]. The content of ammonium and potassium in liquid fertilizers was determined by Opekar et al. [59] and later the simultaneous determination of inorganic cations and anions in the fertilizers was reported by the same group [60]. Sáiz et al. carried out the simultaneous determination of inorganic anions and cations in commercial consumer fireworks which revealed serious inaccuracies of the declared compositions [53].

In addition to the analyses of industrial samples, $\mathrm{CE}$ with $\mathrm{C}^{4} \mathrm{D}$ was applied to the monitoring of various technological processes. Mai et al. employed $C^{4} D$ to evaluate the effectiveness of a covalent coating procedure for the inner walls of CE capillaries in order to eliminate the EOF [105]. Šlampová et al. employed CE-C ${ }^{4} \mathrm{D}$ in the selectivity fine-tuning of an EME procedure [106]. Lan et al. studied the catalytic degradation of Cu-EDTA complexes with CE-C ${ }^{4} \mathrm{D}$ [107]. Ismail et al. used the method to study the decomposition pathways of S-nitrosothiols 
[108] and Kralj et al. employed GEMBE with $\mathrm{C}^{4} \mathrm{D}$ for the total protein determination based on the bicinchoninic acid assay [109].

\subsubsection{Combination of CE-C ${ }^{4} D$ with electromembrane extraction}

The detection limits of CE-C $\mathrm{C}^{4} \mathrm{D}$ are best for small inorganic ions and can reach about $1 \mu \mathrm{M}$, but are not quite as good for larger inorganic or organic ions. Target analytes are also often present at lower concentrations and their direct determination without enrichment is then not possible. Moreover, environmental, food, clinical and other samples have complex matrices which are not suitable for direct injection into $\mathrm{CE}-\mathrm{C}^{4} \mathrm{D}$ due to possible interferences, overloading phenomena or coating of capillary walls. In order to overcome these drawbacks, the combination of CE with electromembrane extraction (EME) procedures has been investigated by several authors. EME is based on electrically induced transfer of ionic compounds from a complex aqueous sample across a thin layer of water immiscible organic membrane into another aqueous receiving solution [110]. Five priority haloacetic acids [102] and bromate [103], which are associated with disinfection processes of potable water, were determined in drinking water samples after selective EME. The combination of the high enrichment power of EME and the sensitive determination of the small ions by $\mathrm{CE}-\mathrm{C}^{4} \mathrm{D}$ ensured LODs of the methods which were significantly below the World Health Organization guideline values. The EME of biological fluids was also shown to be suitable for the sensitive CE-C ${ }^{4} \mathrm{D}$ determination of putrescine and related polyamines in human saliva [80] and for analyses of amphetamine and its derivatives in human plasma [79]. Miniaturized EME ( $\mu$ EME) can be carried out in narrow polymeric capillaries employing $\mu \mathrm{L}$-volumes of adjacent plugs of aqueous and organic solutions and $\mu$-EME combined with $C E-C^{4} D$ was used for the determination of perchlorate in drinking water [101] and for simultaneous determination of basic and acidic drugs in human urine [81]. Polymer inclusion membranes (PIMs), based on 
cellulose acetate, were employed as alternative interface material instead of the commonly used solvent impregnated porous polypropylene membranes, in microextractions of amphetamines [79] and formic acid [111] prior to their CE-C $\mathrm{C}^{4}$ analyses. PIM based hollow fibers and planar PIMs were used for the respective applications demonstrating their sufficient rigidity and suitability for extractions of raw body fluids and for direct coupling of PIM extractions to a commercial CE- $\mathrm{C}^{4} \mathrm{D}$ instrument.

\subsection{Microchip electrophoresis}

Microchip electrophoresis (MCE) offers faster electrically driven separations compared to standard $\mathrm{CE}$ and has for this reason been a popular subject. $\mathrm{C}^{4} \mathrm{D}$ has often been employed in MCE due to the simplicity of this coupling. Please note however, that it is also possible to achieve separations on a timescale of a few seconds when employing short capillaries with $\mathrm{C}^{4} \mathrm{D}$ (see for example [112]). Analyses of real samples by MCE-C ${ }^{4} \mathrm{D}$ are often hampered by the relatively large dimensions of $\mathrm{C}^{4} \mathrm{D}$ cells on MCE-devices compared to the effective lengths of separation microchannels. Indeed, a limited number of MCE-C ${ }^{4} \mathrm{D}$ applications has been reported for analyses of real samples in the reviewed period. A commercial $C^{4} \mathrm{D}$ with external electrode plates combined with lab-made PDMS microchips was shown suitable for separation of a set of inorganic and organic anions in various samples including tap water, saliva and toothpaste [113]. An MCE-C ${ }^{4} \mathrm{D}$ system was used for monitoring of the nitrification process by rapid determination of a set of inorganic anions in various environmental samples [114], see Fig. 6. Determination of histamine in fish flesh after liquid-liquid extraction was reported by Thredgold et al. [115]. Presence of histamine in food samples might be considered an indicator for food degradation and the presented method eliminated the need for derivatization (as normally used with common optical detection methods). It may be adapted 
for analyses of various food samples and offers a high degree of portability for on-site food inspections.

Several studies on the design of MCE-devices in which $\mathrm{C}^{4} \mathrm{D}$ was employed for quantification have also appeared. Soares de Campos et al. investigated the modification of the surface of native PDMS with poly(ethylene glycol) divinyl ether in order to obtain material characteristics suitable for separations of nonpolar analytes [116]. Fundamental microchip characteristics, such as the migration of model inorganic cations and EOF magnitude, were examined for the modified microchips and subsequently, native PDMS and the modified PDMS microchips were compared in terms of adsorption of rhodamine B. A much reduced adsorption of the nonpolar dye was observed for the modified microchips. Laser printer tonerbased technology for the production of PDMS microchips, a cheaper alternative to more advanced and expensive fabrication processes, was examined by Lobo et al. [117]. It was concluded that excellent results can be achieved with this low-cost fabrication technology and the accuracy for standard widths of microfluidic channels $(50-300 \mu \mathrm{m})$ was better than $96 \%$. Recently, Wang and coworkers also proposed a rapid method for prototyping and fabrication of PDMS microfluidic devices for flow-through as well as for electrophoretic applications [118].

A comprehensive list of applications of $\mathrm{C}^{4} \mathrm{D}$ in MCE reported in the last two years is given in Table 2 .

\section{Other applications of $C^{4} D$}

$\mathrm{C}^{4} \mathrm{D}$ is predominantly used in $\mathrm{CE}$ and $\mathrm{MCE}$ (see the former sections), but conductivity measurements are also useful for various other flow-through analytical techniques, including 
LC, capillary LC, flow/sequential injection analysis and in microfluidic platforms. In the reviewed period, several publications on $C^{4} \mathrm{D}$ in IC [33], open-tubular IC [20, 21], capillary IC $[119,120]$ and standard LC [121] were reported. A reversed phase isocratic LC method was optimized for determination of aminoglycosidic antibiotics, which lack UV-absorbing chromophores and are thus not suitable for LC analyses with conventional UV-Vis absorbance detection [121]. Amino acids are an important group of biochemicals with limited UV-absorbing capabilities and are usually detected after derivatization using LIF detection. LC-C ${ }^{4} \mathrm{D}$ was also shown suitable for their determination with no need for the derivatization procedure [121]. $\mathrm{C}^{4} \mathrm{D}$ was also used as a simple and easily adaptable detection technique for determination of inorganic cations in capillary IC [119]. In addition to IC in the capillary format, $\mathrm{C}^{4} \mathrm{D}$ was applied to detection of effluent from standard IC columns; a portable, fully autonomous, IC system was described by Elkin [33]. The system was used for long-term (4 weeks) unattended field operation and for continuous analyses of inorganic anions in environmental samples at a frequency of 4 samples per hour. The repeatability of the portable IC-C $\mathrm{C}^{4} \mathrm{D}$ system for analysis of inorganic anions over 14 days of continuous operation is shown in Fig. 7.

The theory of open-tubular (OT) chromatography suggests that capillary columns with low $\mu \mathrm{m}$ IDs are required in order to achieve good separation efficiencies [122]. Detection in $\sim 1$ $\mu \mathrm{m}$ ID columns is, however, extremely difficult and a serious lack of sensitivity can be expected for most detection techniques. $\mathrm{C}^{4} \mathrm{D}$ ensures high detection sensitivity even with low ID capillaries and CE-C $C^{4} \mathrm{D}$ is regularly carried out in $10 \mu \mathrm{m}$ ID separation capillaries. The admittance detector for low diameter capillaries developed by Dasgupta and coworkers discussed above allowed for sensitive detection in columns down to diameters of $1 \mu \mathrm{m}$ and holds a great promise for further miniaturization in analytical chemistry [19-21]. The 
admittance detector was used for detection in OT-IC $[20,21]$ as well as in flow injection analysis [20].

$\mathrm{C}^{4} \mathrm{D}$ was repeatedly used for structure characterization of monolithic and open-tubular columns for capillary chromatographic methods. Connolly and coworkers [123] immobilized polyaniline, a conductive polymer, on a polystyrene-divinylbenzene monolith and confirmed its immobilization by scanning $\mathrm{C}^{4} \mathrm{D}$ of the entire monolith. In this procedure, the detector is moved in discrete steps along the length of the column for repeated measurements. Scanning $\mathrm{C}^{4} \mathrm{D}$ was also applied for characterization of polymethacrylate monoliths [120]. The monoliths were functionalized by a photo-initiated stepwise grafting procedure and the effect of the stepwise grafting (compared to homogeneous grafting) was subsequently examined by IC analysis of barium and magnesium with on-column $\mathrm{C}^{4} \mathrm{D}$. Another application of scanning $\mathrm{C}^{4} \mathrm{D}$ was reported for characterization of porous open-tubular layers of polystyrene-divinyl benzene bonded onto walls of fused silica photonic crystal fibers (FS-PCFs) [124]. FS-PCFs contain a large number of precisely uniform and parallel micro-channels, offer an increased surface area, and the characterization of the bonding process in multiple channels by means of scanning $\mathrm{C}^{4} \mathrm{D}$ might be advantageous for various analytical applications.

$\mathrm{C}^{4} \mathrm{D}$ might be the detection method of choice in capillaries and tubings which are not optically transparent such as polyether ether ketone (PEEK) tubings. $C^{4} \mathrm{D}$ was recently used to monitor filling and separation procedures in capillary electrokinetic fractionation using a PEEK capillary, which was directly coupled to mass spectrometry [125]. Optical detection is also not possible with packed capillary columns, which are often used in micro-LC and capillary electrochromatography (CEC). Adsorption of mobile phase constituents by the 
separation column during CEC was evidenced by $\mathrm{C}^{4} \mathrm{D}$ and helped elucidate the reasons for non-optimal behaviour in gradient CEC [126].

An interesting use of $C^{4} \mathrm{D}$ is in flow cytometry, i.e. cell counting for medical diagnosis or applications in the life sciences. Sun et al. [127] have presented a new microfluidic device based on insulated planar electrodes for this purpose and demonstrated the counting of human cancer cells. Please note that this topic is closely related to the characterization or counting of cells with impedance measurements, which usually includes the study of the frequency dependence of the signal. Interesting readers are referred to a recent review on this topic [128].

It has been shown that $\mathrm{C}^{4} \mathrm{D}$ can be performed in tubings with much larger dimensions than are normally used in CE and LC separations. Huang and coworkers reported updates on their investigation of the use of $\mathrm{C}^{4} \mathrm{D}$ to determine the fraction of the gaseous phase of gas-liquid two-phase flows in tubes with diameters in the millimetre [129] to centimetre [130] scale. The same research group also reported the development of software to evaluate the data obtained from an electrode array in order to obtain spatially resolved information on the distribution of conductivity inside a tube [131]. 12 electrodes were arranged radially on a pipe of $110 \mathrm{~mm}$ diameter and the system was verified by placing different plastic rods inside the tube, which was filled with tap water. Scheiff et al. [132] employed $C^{4} D$ in a study on heterogeneous catalysis. The detector not only allowed the quantification of electrolytes in the aqueous sections interspersed between sections of immiscible organic solvents, but also the determination of the plug lengths. Oszwałdowski and Kubán̆ used $\mathrm{C}^{4} \mathrm{D}$ to study transport processes of small particles in CE in the presence of micelles [133, 134]. Tůma and Opekar [135] used a $C^{4} \mathrm{D}$-cell to determine the methanol or ethanol content in water, and 
demonstrated this by the analysis of alcoholic beverages. This was possible as the detector showed a response to the permittivity of the medium even in the absence of an electrolyte. In fact traces of salt interfere in the measurement, but this could be alleviated by carrying out the measurement in a CZE approach in which the sample was effectively desalinated by having the ions migrated away from the sample plug before it reached the detector.

The use of $\mathrm{C}^{4} \mathrm{D}$ to monitor reactions in stagnant solutions contained in small vessels has been investigated. Faure et al. [136] used the $C^{4} \mathrm{D}$ approach to monitor an enzymatic hydrolysis reaction. Maier et al. [137] used it to follow the amplification of DNA fragments in a realtime process termed rolling circle amplification (RCA), which is an alternative to the wellknown PCR (polymerase chain reaction) method. For positive samples a change in conductivity was obtained, whereas for negative samples the measured conductivity remained constant. Zhang et al. [138] demonstrated the same approach for a further alternative to PCR known as loop-mediated isothermal amplification (LAMP). $\mathrm{C}^{4} \mathrm{D}$ was also used in a microfluidic platform for on-line monitoring and real-time examination of conductivity changes during a titration process (mixing of hydrochloric acid and sodium hydroxide) [40].

A list of applications of $\mathrm{C}^{4} \mathrm{D}$ in analytical methods other than $\mathrm{CE}$ and $\mathrm{MCE}$ reported in the last two years is given in Table 3 .

\section{Concluding remarks}

The development of $C^{4} \mathrm{D}$ largely followed the trends which were already apparent when the previous review was compiled by the authors two years ago. Most publications concerned the determination of small ions by conventional CE-C ${ }^{4} \mathrm{D}$, while relatively few applications of MCE- $C^{4} \mathrm{D}$ were reported. Fundamental studies concerned the special case of high resistance 
cells and several reports on larger bore tubings and measurements on binary phases appeared. Increasingly more complex procedures incorporating $\mathrm{CE}-\mathrm{C}^{4} \mathrm{D}$ are reported, which include sample treatment and analyte preconcentration, development of field portable instrumentation and of instrumentation with multiple channel separations. It is expected that this trend will continue in the future.

\section{Acknowledgements}

The authors would like to thank the Swiss National Science Foundation (Grant No. 200020149068), the Czech Academy of Sciences (Institutional Support RVO:68081715) and the Grant Agency of the Czech Republic (Grant No. 16-09135S) for financial support. 


\section{References}

[1] Kubáň, P., Hauser, P. C., Electrophoresis 2015, 36, 195-211.

[2] Kubáň, P., Hauser, P. C., Electrophoresis 2013, 34, 55-69.

[3] Kubáň, P., Hauser, P. C., Electrophoresis 2011, 32, 30-42.

[4] Kubáň, P., Hauser, P. C., Electrophoresis 2009, 30, 176-188.

[5] Zemann, A. J., Schnell, E., Volgger, D., Bonn, G. K., Anal. Chem. 1998, 70, 563567.

[6] da Silva, J. A. F., do Lago, C. L., Anal. Chem. 1998, 70, 4339-4343.

[7] Zemann, A. J., TrAC-Trends Anal. Chem. 2001, 20, 346-354.

[8] Zemann, A. J., Electrophoresis 2003, 24, 2125-2137.

[9] Guijt, R. M., Evenhuis, C. J., Macka, M., Haddad, P. R., Electrophoresis 2004, 25, 4032-4057.

[10] Šolínová, V., Kašička, V., J. Sep. Sci. 2006, 29, 1743-1762.

[11] Pumera, M., Talanta 2007, 74, 358-364.

[12] Matysik, F. M., Microchim. Acta 2008, 160, 1-14.

[13] Trojanowicz, M., Anal. Chim. Acta 2009, 653, 36-58.

[14] Mark, J. J. P., Scholz, R., Matysik, F. M., J. Chromatogr. A 2012, 1267, 45-64.

[15] Coltro, W. K. T., Lima, R. S., Segato, T. P., Carrilho, E., de Jesus, D. P., do Lago, C. L., da Silva, J. A. F., Anal. Methods 2012, 4, 25-33.

[16] Elbashir, A. A., Aboul-Enein, H. Y., Biomed. Chromatogr. 2010, 24, 1038-1044.

[17] Elbashir, A. A., Aboul-Enein, H. Y., Biomed. Chromatogr. 2012, 26, 990-1000.

[18] Elbashir, A. A., Aboul-Enein, H. Y., Biomed. Chromatogr. 2014, 28, 1502-1506.

[19] Zhang, M., Stamos, B. N., Amornthammarong, N., Dasgupta, P. K., Anal. Chem. $2014,86,11538-11546$.

[20] Zhang, M., Stamos, B. N., Dasgupta, P. K., Anal. Chem. 2014, 86, 11547-11553. 
[21] Yang, B., Zhang, M., Kanyanee, T., Stamos, B. N., Dasgupta, P. K., Anal. Chem. $2014,86,11554-11561$.

[22] Kubáň, P., Hauser, P. C., Electrophoresis 2004, 25, 3387-3397.

[23] Kubáň, P., Müri, M. A., Hauser, P. C., The Analyst 2004, 129, 82-86.

[24] Opekar, F., Tůma, P., Štulík, K., Sensors 2013, 13, 2786-2801.

[25] Johnston, S. E., Fadgen, K. E., Tolley, L. T., Jorgenson, J. W., J. Chromatogr. A 2005, 1094, 148-157.

[26] Brito-Neto, J. G. A., da Silva, J. A. F., Blanes, L., do Lago, C. L., Electroanalysis $2005,17,1198-1206$.

[27] Brito-Neto, J. G. A., da Silva, J. A. F., Blanes, L., do Lago, C. L., Electroanalysis $2005,17,1207-1214$.

[28] Kubán̆, P., Hauser, P. C., Electrophoresis 2004, 25, 3398-3405.

[29] Kubáň, P., Hauser, P. C., Electrophoresis 2009, 30, 3305-3314.

[30] Mai, T. D., Hauser, P. C., Chem. Rec. 2012, 12, 106-113.

[31] Drevinskas, T., Kaljurand, M., Maruška, A., Electrophoresis 2014, 35, 2401-2407.

[32] Drevinskas, T., Maruška, A., Briedis, V., Electrophoresis 2015, 36, 292-297.

[33] Elkin, K. R., J. Chromatogr. A 2014, 1352, 38-45.

[34] Takeuchi, M., Li, Q. Y., Yang, B. C., Dasgupta, P. K., Wilde, V. E., Talanta 2008, $76,617-620$.

[35] Zheng, H., Li, M., Dai, J. Y., Wang, Z., Li, X. T., Yuan, H. Y., Xiao, D., Anal. Chem. 2014, 86, 10065-10070.

[36] Nguyen, D. H., Vu, Q. T., Do, Q. L., Nguyen, H. H., Trinh, C. D., Microsyst. Technol. 2015, 21, 1-10.

[37] Ji, H., Lyu, Y., Wang, B., Huang, Z., Li, H., Yan, Y., Sens. Actuator A-Phys. 2015, $235,273-280$. 
[38] Ji, H. F., Li, Z. Z., Wang, B. L., Huang, Z. Y., Li, H. Q., Yan, Y., Sens. Actuator APhys. 2014, 213, 1-8.

[39] Lyu, Y., Ji, H., Yang, S., Huang, Z., Wang, B., Li, H., Sensors 2016, 16.

[40] da Costa, E. T., Mora, M. F., Willis, P. A., do Lago, C. L., Jiao, H., Garcia, C. D., Electrophoresis 2014, 35, 2370-2377.

[41] https://sites.google.com/site/openc4d/home, accessed on May 25, 2016.

[42] Yan, X., Liu, W., Yuan, Y., Chen, C., Anal. Methods 2015, 7, 5295-5302.

[43] Chagas, C. L. S., Duarte, L. C., Lobo-Júnior, E. O., Piccin, E., Dossi, N., Coltro, W. K. T., Electrophoresis 2015, 36, 1837-1844.

[44] Kubáň, P., Hauser, P. C., Lab Chip 2005, 5, 407-415.

[45] Duarte Junior, G. F., Fracassi da Silva, J. A., Mendonca Francisco, K. J., do Lago, C. L., Carrilho, E., Coltro, W. K. T., Electrophoresis 2015, 36, 1935-1940.

[46] https://hackaday.io/project/6835-c4derpillar-open-ce-cd, accessed on May 25, 2016.

[47] Ryvolová, M., Preisler, J., Brabazon, D., Macka, M., TrAC-Trends Anal. Chem. 2010, 29, 339-353.

[48] Lewis, A. P., Cranny, A., Harris, N. R., Green, N. G., Wharton, J. A., Wood, R. J. K., Stokes, K. R., Meas. Sci. Technol. 2013, 24.

[49] Van Schepdael, A., Chromatography 2016, 3.

[50] Nguyen, T. A. H., Pham, T. N. M., Doan, T. T., Ta, T. T., Sáiz, J., Nguyen, T. Q. H., Hauser, P. C., Mai, T. D., J. Chromatogr. A 2014, 1360, 305-311.

[51] Nguyen, T. A. H., Pham, T. N. M., Ta, T. T., Nguyen, X. T., Nguyen, T. L., Le, T. H. H., Koenka, I. J., Sáiz, J., Hauser, P. C., Mai, T. D., Sci. Justice 2015, 55, 481486.

[52] Duong, H. A., Le, M. D., Nguyen, K. D. M., Hauser, P. C., Pham, H. V., Mai, T. D., Environ. Sci.: Processes Impacts 2015, 17, 1941-1951. 
[53] Sáiz, J., Duc, M. T., Koenka, I. J., Martín-Alberca, C., Hauser, P. C., García-Ruiz, C., J. Chromatogr. A 2014, 1372, 245-252.

[54] Mai, T. D., Le, M. D., Sáiz, J., Duong, H. A., Koenka, I. J., Pham, H. V., Hauser, P. C., Anal. Chim. Acta 2016, 911, 121-128.

[55] Gorbatsova, J., Jaanus, M., Vaher, M., Kaljurand, M., Electrophoresis 2016, 37, 472475.

[56] Greguš, M., Foret, F., Kubáň, P., J. Chromatogr. A 2016, 1427, 177-185.

[57] Chaisuwan, P., Moonta, T., Sangcakul, A., Nacapricha, D., Wilairat, P., Uraisin, K., J. Sep. Sci. 2015, 38, 1035-1041.

[58] Makrlíková, A., Opekar, F., Tůma, P., Electrophoresis 2015, 36, 1962-1968.

[59] Opekar, F., Nesměrák, K., Tůma, P., Electrophoresis 2016, 37, 595-600.

[60] Opekar, F., Tůma, P., J. Chromatogr. A 2016, 1446, 158-163.

[61] Pham, T. T. T., Mai, T. D., Nguyen, T. D., Sáiz, J., Pham, H. V., Hauser, P. C., Anal. Chim. Acta 2014, 841, 77-83.

[62] Koenka, I. J., Sáiz, J., Rempel, P., Hauser, P. C., Anal. Chem. 2016, 88, 3761-3767.

[63] Sáiz, J., Koenka, I. J., García-Ruiz, C., Müller, B., Chwalek, T., Hauser, P. C., Electrophoresis 2015, 36, 1941-1944.

[64] Tycova, A., Foret, F., J. Chromatogr. A 2015, 1388, 274-279.

[65] Caslavska, J., Koenka, I. J., Hauser, P. C., Thormann, W., Electrophoresis 2016, 37, 699-710.

[66] Caslavska, J., Mosher, R. A., Thormann, W., Electrophoresis 2015, 36, 1529-1538.

[67] Mai, T. D., Hauser, P. C., Electrophoresis 2011, 32, 3000-3007.

[68] Mai, T. D., Hauser, P. C., Talanta 2011, 84, 1228-1233.

[69] Mai, T. D., Hauser, P. C., J. Chromatogr. A 2012, 1267, 266-272.

[70] Mai, T. D., Hauser, P. C., Electrophoresis 2013, 34, 1796-1803. 
[71] Porto, S. K. S. S., Nogueira, T., Blanes, L., Doble, P., Sabino, B. D., do Lago, C. L., Angnes, L., J. Forensic Sci. 2014, 59, 1622-1626.

[72] Cunha, R. R., Chaves, S. C., Ribeiro, M. M. A. C., Torres, L. M. F. C., Muñoz, R. A. A., Dos Santos, W. T. P., Richter, E. M., J. Sep. Sci. 2015, 38, 1657-1662.

[73] Marra, M. C., Silva, P. L., Muñoz, R. A. A., Richter, E. M., J. Braz. Chem. Soc. 2014, 25, 913-919.

[74] Tůma, P., Gojda, J., Electrophoresis 2015, 36, 1969-1975.

[75] Tůma, P., J. Chromatogr. A 2014, 1345, 207-211.

[76] Mazina, J., Saar-Reismaa, P., Kulp, M., Kaljurand, M., Vaher, M., Electrophoresis $2015,36,3042-3049$.

[77] Thang, L. Y., Shahir, S., See, H. H., Electrophoresis 2015, 36, 2713-2719.

[78] Pantůčková, P., Kubáň, P., Boček, P., Anal. Chim. Acta 2015, 887, 111-117.

[79] Mamat, N. A., See, H. H., J. Chromatogr. A 2015, 1406, 34-39.

[80] Liu, Y., Zhang, X. L., Guo, L., Zhang, Y., Li, Z., Wang, Z. Y., Huang, M. F., Yang, C., Ye, J. N., Chu, Q. C., Talanta 2014, 128, 386-392.

[81] Kubáň, P., Boček, P., Anal. Chim. Acta 2016, 908, 113-120.

[82] Greguš, M., Foret, F., Kubáň, P., Electrophoresis 2015, 36, 526-533.

[83] Greguš, M., Foret, F., Kindlová, D., Pokojová, E., Plutinský, M., Doubková, M., Merta, Z., Binková, I., Skřričková, J., Kubáň, P., J. Breath Res. 2015, 9, No. 027107.

[84] Guo, L., Wang, Y., Zheng, Y. L., Huang, Z. P., Cheng, Y. Y., Ye, J. N., Chu, Q. C., Huang, D. P., J. Chromatogr. B 2016, 1014, 70-74.

[85] Mori, M., Ishikawara, F., Tomoda, T., Yamada, S., Okamoto, M., Itabashi, H., Seki, Y., Matsumoto, R., Shoho, Y., Martha, L., Sumino, H., Murakami, M., J. Chromatogr. B 2016, 1012, 178-185. 
[86] Ji, Y. L., Chen, X. W., Zhang, Z. B., Li, J., Xie, T. Y., J. Sep. Sci. 2014, 37, 30003006.

[87] Kubáň, P., Greguš, M., Pokojová, E., Skřičková, J., Foret, F., J. Chromatogr. A 2014, 1358, 293-298.

[88] Vontobel, S. F., Abad-Villar, E. M., Kaufmann, C., Zinkernagel, A. S., Hauser, P. C., Thiel, M. A., J. Clin. Exp. Ophthalmol. 2015, 6, No. 1000430.

[89] Wei, Y., Chen, Y. F., Zhou, Q., Yuan, Q. Y., Tan, F. Y., Xie, T. Y., Chem. J. Chin. Univ. 2014, 35, 1409-1413.

[90] Keyon, A. S. A., Guijt, R. M., Bolch, C. J. S., Breadmore, M. C., J. Chromatogr. A 2014, 1364, 295-302.

[91] Keyon, A. S. A., Guijt, R. M., Gaspar, A., Kazarian, A. A., Nesterenko, P. N., Bolch, C. J., Breadmore, M. C., Electrophoresis 2014, 35, 1496-1503.

[92] Tian, Z. R., Qin, W. D., Anal. Methods 2014, 6, 5353-5359.

[93] Drevinskas, T., Bartkuviene, V., Maruška, A., Chemija 2014, 25, 206-212.

[94] Mádr, A., Celá, A., Klejdus, B., Pelcová, M., Crha, I., Žáková, J., Glatz, Z., Electrophoresis 2015, 36, 1244-1250.

[95] Yang, L. R., Zhou, S. L., Xiao, Y. Z., Tang, Y. F., Xie, T. Y., Food Chem. 2015, $188,446-451$.

[96] Campos, C. D. M., Braga, P. A. D., Reyes, F. G. R., da Silva, J. A. F., J. Sep. Sci. $2015,38,3781-3787$.

[97] Lemos, M. A. T., Pinheiro, A. M., Cassella, R. J., Jesus, D. P., Anal. Methods 2014, 6, 3629-3633.

[98] Lemos, M. A. T., Cassella, R. J., de Jesus, D. P., Food Control 2015, 57, 327-332.

[99] Wu, J. Q., Ge, Y., Qin, W. D., J. Agric. Food Chem. 2014, 62, 4104-4111. 
[100] Böckel, W. J., da Silva, Y. P., Mendonca, C. R. B., Simó-Alfonso, E. F., RamisRamos, G., Piatnicki, C. M. S., J. Braz. Chem. Soc. 2014, 25, 1662-1666.

[101] Kubáň, P., Boček, P., Anal. Chim. Acta 2014, 848, 43-50.

[102] Zhang, X. L., Zhang, H. T., Liu, Y., Guo, L., Ye, J. N., Chu, Q. C., Chin. J. Chem. $2015,33,235-240$.

[103] Zhang, X. L., Guo, L., Zhang, D. X., Ge, X. X., Ye, J. N., Chu, Q. C., Food Anal. Methods 2016, 9, 393-400.

[104] Marques, T. T., Shiroma, L. S., de Jesus, D. P., J. Sep. Sci. 2015, 38, 852-857.

[105] Mai, T. D., d'Orlyé, F., Varenne, A., Chromatographia 2015, 78, 775-783.

[106] Šlampová, A., Kubáň, P., Boček, P., Electrophoresis 2014, 35, 3317-3320.

[107] Lan, S. Y., Xiong, Y., Tian, S. H., Sun, L. P., Xie, T. Y., Wang, X., Kong, L. J., Electroanalysis 2014, 26, 2534-2540.

[108] Ismail, A., d'Orlyé, F., Griveau, S., Bedioui, F., Varenne, A., da Silva, J. A. F., Electrophoresis 2015, 36, 1982-1988.

[109] Kralj, J. G., Munson, M. S., Ross, D., Electrophoresis 2014, 35, 1887-1892.

[110] Pedersen-Bjergaard, S., Rasmussen, K. E., J. Chromatogr. A 2006, 1109, 183-190.

[111] Pantůčková, P., Kubáň, P., Boček, P., J. Chromatogr. A 2015, 1389, 1-7.

[112] Wuersig, A., Kubáň, P., Khaloo, S. S., Hauser, P. C., The Analyst 2006, 131, 944949.

[113] Koczka, P. I., Bodoki, E., Gáspár, A., Electrophoresis 2016, 37, 398-405.

[114] Freitas, C. B., Moreira, R. C., de Oliveira Tavares, M. G., Coltro, W. K. T., Talanta $2016,147,335-341$.

[115] Thredgold, L. D., Ellis, A. V., Lenehan, C. E., Anal. Methods 2015, 7, 1802-1808.

[116] Soares de Campos, R. P., Pagotto Yoshida, I. V., Fracassi da Silva, J. A., Electrophoresis 2014, 35, 2346-2352. 
[117] Lobo Júnior, E. d. O., Duarte, L. d. C., de Paula Braga, L. E., Gobbi, A. L., de Jesus, D. P., Tomazelli Coltro, W. K., Microsyst. Technol. 2015, 21, 1345-1352.

[118] Wang, L., Liu, W. F., Li, S., Liu, T. T., Yan, X. X., Shi, Y. Y., Cheng, Z. N., Chen, C. P., Microsyst. Technol. 2016, 22, 677-686.

[119] Earnestly, F., Lim, L. W., Takeuchi, T., Chromatographia 2014, 77, 1539-1544.

[120] Currivan, S., Connolly, D., Paull, B., J. Sep. Sci. 2015, 38, 3795-3802.

[121] Jankovics, P., Chopra, S., El-Attug, M. N., Cabooter, D., Wolfs, K., Noszál, B., Van Schepdael, A., Adams, E., J. Pharm. Biomed. Anal. 2015, 112, 155-168.

[122] Knox, J. H., Gilbert, M. T., J. Chromatogr. 1979, 186, 405-418.

[123] Floris, P., Connolly, D., White, B., Morrin, A., RSC Adv. 2014, 4, 43934-43941.

[124] Kazarian, A. A., Rodriguez, E. S., Deverell, J. A., McCord, J., Muddiman, D. C., Paull, B., Anal. Chim. Acta 2016, 905, 1-7.

[125] He, Y., Harir, M., Chen, G., Gougeon, R. D., Zhang, L., Huang, X., SchmittKopplin, P., Electrophoresis 2014, 35, 1965-1975.

[126] Kitagawa, S., Buno, H., Sakabe, K., Nakagawa, H., Ohtani, H., J. Sep. Sci. 2014, 37, 3181-3187.

[127] Sun, D. P., Lu, J., Chen, Z. G., RSC Adv. 2015, 5, 59306-59313.

[128] Xu, Y., Xie, X., Duan, Y., Wang, L., Cheng, Z., Cheng, J., Biosens. Bioelectron. $2016,77,824-836$.

[129] Zhou, Y., Huang, Z., Wang, B., Ji, H., Li, H., Int. J. Multiphase Flow 2015, 72, 298305.

[130] Ji, H., Chang, Y., Huang, Z., Wang, B., Li, H., Flow Meas. Instrument. 2014, 40, 199-205.

[131] Wang, B. L., Tan, W. H., Huang, Z. Y., Ji, H. F., Li, H. Q., Flow Meas. Instrument. 2014, 40, 216-222. 
[132] Scheiff, F., Neemann, F., Tomasiak, S. J., Agar, D. W., Chem. Ing. Tech. 2014, 86, 504-518.

[133] Oszwaldowski, S., Kubáň, P., J. Chromatogr. A 2015, 1412, 139-150.

[134] Oszwaldowski, S., Kubáň, P., Anal. Chim. Acta 2015, 864, 85-93.

[135] Tůma, P., Opekar, F., Electrophoresis 2015, 36, 1976-1981.

[136] Faure, M., Sotta, B., Gamby, J., Biosensors Bioelectronics 2014, 58, 61-67.

[137] Maier, T., Kainz, K., Barišić, I., Hainberger, R., Int. J. Electrochem. Sci. 2015, 10, 2026-2034.

[138] Zhang, X. Z., Li, Q. F., Jin, X. S., Jiang, C., Lu, Y., Tavallaie, R., Gooding, J. J., Sci. Reports 2015, 5 .

[139] Gao, F., Wu, M. L., Zhang, Y., Wang, G., Wang, Q. J., He, P. G., Fang, Y. Z., J. Chromatogr. B 2014, 973, 29-32.

[140] Kler, P. A., Huhn, C., Anal. Bioanal. Chem. 2014, 406, 7163-7174.

[141] Lan, S. Y., Xiong, Y., Tian, S. H., Feng, J. X., Xie, T. Y., Appl. Catalysis B: Environ. 2016, 183, 371-376.

[142] Beutner, A., Cunha, R. R., Richter, E. M., Matysik, F. M., Electrophoresis 2016, 37, 931-935. 
Table 1. Applications of $\mathrm{C}^{4} \mathrm{D}$ in conventional CE.

\begin{tabular}{|c|c|c|c|c|c|c|}
\hline Analytes & BGE composition & $\mathrm{C}^{4} \mathrm{D}$ parameters & Mode & $\begin{array}{l}\text { Sample } \\
\text { type }\end{array}$ & LODs & Ref. \\
\hline \multicolumn{7}{|l|}{ Food analysis } \\
\hline \multirow[t]{2}{*}{$\begin{array}{l}\text { Artificial } \\
\text { sweeteners }\end{array}$} & $\begin{array}{l}30 \mathrm{mM} \text { CHES, } 100 \mathrm{mM} \text { Tris, } \mathrm{pH} \\
9.1\end{array}$ & $200 \mathrm{~V}_{\mathrm{pp}}, 400 \mathrm{kHz}$ & $\begin{array}{l}\text { Portable } \\
\text { CZE }\end{array}$ & $\begin{array}{l}\text { Fish sauce, } \\
\text { soft drinks }\end{array}$ & $\begin{array}{l}1.5-6.5 \\
\mu \mathrm{M}\end{array}$ & {$[54]$} \\
\hline & $20 \mathrm{mM}$ acetic acid & $200 \mathrm{~V}_{\mathrm{pp}}, 350 \mathrm{kHz}$ & FASI-CZE & $\begin{array}{l}\text { Chinese } \\
\text { beverages }\end{array}$ & $\begin{array}{l}4.4-8.8 \\
\mu \mathrm{g} / \mathrm{L}\end{array}$ & {$[95]$} \\
\hline $\operatorname{Beta}(2)$-agonists & $\begin{array}{l}5 \mathrm{mM} \text { Tris, } 10 \mathrm{mM} \text { citric acid, } \\
\text { pH } 3.2\end{array}$ & $\begin{array}{l}\text { eDAQ ER } 125 \\
50 \mathrm{~V}_{\mathrm{pp}}, 750 \mathrm{kHz}\end{array}$ & FASI-CZE & Pig feed & $\begin{array}{l}0.02 \\
\mathrm{mg} / \mathrm{L}\end{array}$ & [139] \\
\hline Beta-agonists & $\begin{array}{l}10 \mathrm{mM} \text { Arg, adjusted to } \mathrm{pH} 4.9 \\
\text { with acetic acid }\end{array}$ & $200 \mathrm{~V}_{\mathrm{pp}}, 400 \mathrm{kHz}$ & $\begin{array}{l}\text { Portable } \\
\text { CZE }\end{array}$ & Pig feed & $\begin{array}{l}0.5-0.7 \\
\mathrm{mg} / \mathrm{L}\end{array}$ & {$[50]$} \\
\hline Fatty acids & $\begin{array}{l}3 \mathrm{mM} \text { pelargonic acid, } 39 \mathrm{mM} \\
\text { Tris, } 30 \mathrm{mM} \text { Brij } 35,35 \%(\mathrm{v} / \mathrm{v}) \\
\mathrm{ACN}, 15 \%(\mathrm{v} / \mathrm{v}) 2 \text {-propanol, } \\
2.5 \%(\mathrm{v} / \mathrm{v}) 1 \text {-octanol, } 300 \mu \mathrm{M} \\
\text { polyamidoamine } \mathrm{G} 2, \mathrm{pH} 8.53\end{array}$ & $20 \mathrm{~V}_{\mathrm{pp}}, 100 \mathrm{kHz}$ & CZE & Edible oils & $\begin{array}{l}0.46- \\
3.28 \mu \mathrm{M}\end{array}$ & [99] \\
\hline $\begin{array}{l}\text { Glutamic acid in } \\
\text { presence of other } \\
\text { amino acids }\end{array}$ & $5 \mathrm{M}$ acetic acid, $\mathrm{pH} 2$ & $2 \mathrm{~V}_{\mathrm{pp}}, 550 \mathrm{kHz}$ & $\mathrm{CZE}$ & Soy sauce & $59.2 \mu \mathrm{M}$ & [96] \\
\hline Inorganic anions & $\begin{array}{l}12 \mathrm{mM} \text { His, adjusted to } \mathrm{pH} 4 \\
\text { with acetic acid }\end{array}$ & $200 \mathrm{~V}_{\mathrm{pp}}, 400 \mathrm{kHz}$ & $\begin{array}{l}\text { Portable } \\
\text { CZE }\end{array}$ & $\begin{array}{l}\text { Beer, wine, } \\
\text { soft drinks }\end{array}$ & $\begin{array}{l}2-6 \\
\mu \mathrm{M}\end{array}$ & {$[54]$} \\
\hline $\begin{array}{l}\text { Inorganic anions } \\
\text { and formate }\end{array}$ & $\begin{array}{l}15 \mathrm{mM} \text { His, adjusted to } \mathrm{pH} 4.7 \\
\text { with lactic acid }\end{array}$ & $2 \mathrm{~V}_{\mathrm{pp}}, 610 \mathrm{kHz}$ & $\mathrm{CZE}$ & $\begin{array}{l}\text { Virgin olive } \\
\text { oil }\end{array}$ & $\begin{array}{l}10-700 \\
\mu \mathrm{g} / \mathrm{L} \\
\text { (LOQs) }\end{array}$ & {$[98]$} \\
\hline \multirow[t]{2}{*}{ Inorganic cations } & $\begin{array}{l}20 \mathrm{mM} \text { His, } 22 \mathrm{mM} \text { lactic acid, } \\
\mathrm{pH} 4.7\end{array}$ & $1.5 \mathrm{~V}_{\mathrm{pp}}, 600 \mathrm{kHz}$ & CZE & $\begin{array}{l}\text { Virgin olive } \\
\text { oil }\end{array}$ & $\begin{array}{l}43-67 \\
\mu \mathrm{g} / \mathrm{L}\end{array}$ & [97] \\
\hline & $\begin{array}{l}12 \mathrm{mM} \text { His, } 2 \mathrm{mM} \text { 18-crown-6, } \\
\text { adjusted to } \mathrm{pH} 3.7 \text { with acetic } \\
\text { acid }\end{array}$ & $200 \mathrm{~V}_{\mathrm{pp}}, 400 \mathrm{kHz}$ & $\begin{array}{l}\text { Portable } \\
\text { CZE }\end{array}$ & $\begin{array}{l}\text { Beer, wine, } \\
\text { soft drinks }\end{array}$ & $\begin{array}{l}1.2-3 \\
\mu \mathrm{M}\end{array}$ & {$[54]$} \\
\hline Oleic acid & $\begin{array}{l}\mathrm{MeOH} / 1 \text {-propanol }(1 / 6, \mathrm{v} / \mathrm{v}) \\
\text { containing } 40 \mathrm{mM} \mathrm{KOH} \text { and } \\
10 \%(\mathrm{v} / \mathrm{v}) \text { ethylene glycol }\end{array}$ & $8 \mathrm{~V}_{\mathrm{pp}}, 550 \mathrm{kHz}$ & NACE & Soybean oil & $24 \mu \mathrm{M}$ & {$[100]$} \\
\hline Organic anions & $\begin{array}{l}90 \text { mM MES, } 90 \text { mM His, } 20 \\
\mu \text { C CTAB }\end{array}$ & $200 \mathrm{~V}_{\mathrm{pp}}, 400 \mathrm{kHz}$ & $\begin{array}{l}\text { Portable } \\
\text { CZE }\end{array}$ & $\begin{array}{l}\text { Beer, wine, } \\
\text { soft drinks }\end{array}$ & $\begin{array}{l}1.4-20 \\
\mu \mathrm{M}\end{array}$ & {$[54]$} \\
\hline \multicolumn{7}{|c|}{ Pharmaceutical, clinical and other complex sample analysis } \\
\hline $\begin{array}{l}\text { Analgesic and } \\
\text { antipyretic drugs }\end{array}$ & $\begin{array}{l}10 \mathrm{mM} 3,4- \\
\text { dimethoxycinnamate, } 12 \mathrm{mM} \\
\text { triethanolamine, } \mathrm{pH} 8.5\end{array}$ & $4 \mathrm{~V}_{\mathrm{pp}}, 1.1 \mathrm{MHz}$ & CZE & $\begin{array}{l}\text { Pharmaceut } \\
\text { icals }\end{array}$ & $\begin{array}{l}20-60 \\
\mu \mathrm{M}\end{array}$ & {$[73]$} \\
\hline Beta-agonists & $\begin{array}{l}10 \mathrm{mM} \text { Arg, adjusted to } \mathrm{pH} 4.9 \\
\text { with acetic acid }\end{array}$ & $200 \mathrm{~V}_{\mathrm{pp}}, 400 \mathrm{kHz}$ & $\begin{array}{l}\text { Portable } \\
\text { CZE }\end{array}$ & $\begin{array}{l}\text { Pharmaceut } \\
\text { icals }\end{array}$ & $\begin{array}{l}0.5-0.7 \\
\mathrm{mg} / \mathrm{L}\end{array}$ & {$[50]$} \\
\hline $\begin{array}{l}\text { Caffeine, } \\
\text { ibuprofen, } \\
\text { paracetamol }\end{array}$ & $\begin{array}{l}10 \mathrm{mM} 3,4- \\
\text { dimethoxycinnamate, } 10 \mathrm{mM} \\
\text { beta-alanine, adjusted to } \mathrm{pH} 10.4 \\
\text { with } \mathrm{LiOH}\end{array}$ & $4 \mathrm{~V}_{\mathrm{pp}}, 1.1 \mathrm{MHz}$ & $\mathrm{CZE}$ & $\begin{array}{l}\text { Pharmaceut } \\
\text { icals }\end{array}$ & $\begin{array}{l}32-49 \\
\mu \mathrm{M}\end{array}$ & {$[72]$} \\
\hline Colistin & 5 mM MES, 5 mM His, pH 6.0 & $\begin{array}{l}\text { eDAQ ET120, } \\
100 \mathrm{~V}_{\mathrm{pp}}, 400 \mathrm{kHz}\end{array}$ & FI-CZE & $\begin{array}{l}\text { Pharmaceut } \\
\text { icals }\end{array}$ & $\begin{array}{l}20 \mathrm{mg} / \mathrm{L} \\
(\mathrm{LOQ})\end{array}$ & {$[57]$} \\
\hline $\begin{array}{l}\text { Creatinine, } \\
\text { histidine }\end{array}$ & $\begin{array}{l}50 \mathrm{mM} \text { MES, } 5 \mathrm{mM} \mathrm{NaOH}, \mathrm{pH} \\
5.1\end{array}$ & $17 \mathrm{~V}_{\mathrm{pp}}, 450 \mathrm{kHz}$ & SI-CZE & Urine & n.r. & {$[58]$} \\
\hline $\begin{array}{l}\text { Creatinine, } \\
\text { histidine, } \\
\text { inorganic cations }\end{array}$ & $\begin{array}{l}1 \mathrm{M} \text { acetic acid, } 1.5 \mathrm{mM} 18- \\
\text { crown-6, pH } 2.4\end{array}$ & $17 \mathrm{~V}_{\mathrm{pp}}, 450 \mathrm{kHz}$ & SI-CZE & Urine & n.r. & {$[58]$} \\
\hline Formate & $20 \mathrm{mM}$ His, $70 \mathrm{mM}$ acetic acid, & Admet, $50 \mathrm{~V}_{\mathrm{pp}}$, & PIM-CZE & Blood, & $15-54$ & {$[78]$} \\
\hline
\end{tabular}


$\mathrm{pH} 4.3$

Formate in
presence of inorganic/organic

$15 \mathrm{mM}$ glutamic acid, $10 \mathrm{mM}$ His, $30 \mu \mathrm{M}$ CTAB, pH 4.6

anions

Gama-

acid

$8.5 \mathrm{mM}$ maleic acid, $17 \mathrm{mM}$ arginine, $255 \mu \mathrm{M}$ CTAB, $15 \%$ (v/v) ACN

Histamine, melittin

$1 \mathrm{M}$ acetic acid, $\mathrm{pH} 2.4$ hydroxybutyric

$1.84 \mathrm{MHz}$

Admet, $50 \mathrm{~V}$ $1.84 \mathrm{MHz}$

Portable

CZE

V n.r., $150 \mathrm{kHz}$

Portable CZE

$\mathrm{AD} 7745,3.3 \mathrm{~V}_{\mathrm{pp}}, \mathrm{CZE}$, $32 \mathrm{kHz}$

Chlorogenic acid, 75 mM L-ascorbic acid, pH 2.7 citric acid, pigments

$\mathrm{N}, \mathrm{N}$-dimethylformamide, acetic acid

Inorganic anions, organic anions

$60 \mathrm{mM}$ MES, $60 \mathrm{mM}$ His, 30 $\mu \mathrm{M}$ CTAB, 2 mM 18-crown-6, pH 6.0

$20 \mathrm{mM}$ MES, $20 \mathrm{mM}$ His, 30 $\mu \mathrm{M}$ CTAB, 2 mM 18-crown-6, pH 6.0

Inorganic cations $60 \mathrm{mM}$ MES, $60 \mathrm{mM}$ His, 30 $\mu \mathrm{M}$ CTAB, 2 mM 18-crown-6, pH 6.0

Inorganic cations and anions Inorganic cations, inorganic and organic anions

$20 \mathrm{mM}$ MES, $20 \mathrm{mM}$ His, $2 \mathrm{mM}$ 18-crown-6, pH 6.0

$60 \mathrm{mM}$ MES, $60 \mathrm{mM}$ His, 30 $\mu \mathrm{M}$ CTAB, 2 mM 18-crown-6, pH 6.0 $20 \mathrm{mM}$ MES, $20 \mathrm{mM}$ His, 1.5 mM 18-crown-6, pH 6.0

Lactate, pyruvate

$10 \mathrm{mM}$ MES adjusted to $\mathrm{pH} 6.5$ with $\mathrm{LiOH}$

MDMA, MA, $10 \mathrm{mM}$ Arg adjusted to $\mathrm{pH} 4.5$ MDA, MDEA with acetic acid

MDMA, MA, $\quad 600 \mathrm{mM}$ acetic acid amphetamine

MDMA, mCPP

$20 \mathrm{mM}$ TAPS, adjusted to $\mathrm{pH}$ 8.7 with $\mathrm{LiOH}$

Melamine

$12 \mathrm{mM}$ acetic acid, $10 \mathrm{mM}$ sodium acetate, $\mathrm{pH} 4.6$

Metformin

$2 \mathrm{M}$ acetic acid, $\mathrm{pH} 2.15$

$\mathrm{NH}_{4}{ }^{+}$stacker

5.2 $\mathrm{M}$ acetic acid

monitoring in

tITP-CZE

Polyamines

$500 \mathrm{mM}$ acetic acid, $180 \mathrm{mM}$

18-crown-6, pH 2.5

Polyhexamethyle $\quad 2.3 \mathrm{M}$ acetic acid, $0.05 \%$ Tween ne biguanide, chlorhexidine Procaine, 20

20 mM CHES, 10 mM L-Arg,

\section{Admet, $50 \mathrm{~V}$ \\ $1.84 \mathrm{MHz}$}

Admet, $50 \mathrm{~V}_{\mathrm{pp}}$, Portable $1.84 \mathrm{MHz}$

CZE

Admet, $50 \mathrm{~V}_{\mathrm{pp}}, \quad \mathrm{CZE}$ $1.84 \mathrm{MHz}$

$20 \mathrm{~V}_{\mathrm{pp}}, 300 \mathrm{kHz}$

Admet, $50 \mathrm{~V}_{\mathrm{pp}}$,

$1.84 \mathrm{MHz}$

TraceDec

Admet, $50 \mathrm{~V}_{\mathrm{pp}}, 1 \mathrm{CZE}$ $\mathrm{MHz}$

$200 \mathrm{~V}_{\mathrm{pp}}, 400 \mathrm{kHz}$ Portable CZE

\section{eDAQ, $100 \%$ amplitude, 1.3} $\mathrm{MHz}$

$4 \mathrm{~V}_{\mathrm{pp}}, 1.2 \mathrm{MHz}$

CZE, portable $\mathrm{C}^{4} \mathrm{D}$

n.r.

FASI-CZE Milk

Admet, $50 \mathrm{~V}_{\mathrm{pp}}$, $1.84 \mathrm{MHz}$

LVSS-CZE Urine, plasma

Admet, $50 \mathrm{~V}_{\mathrm{pp}}$, $1.84 \mathrm{MHz}$

eDAQ ER125, $60 \mathrm{~V}_{\mathrm{pp}}, 550 \mathrm{kHz}$

$400 \mathrm{~V}_{\mathrm{pp}}, 200 \mathrm{kHz} \quad \mathrm{CZE}$

EME-CZE

Urine,

plasma

Saliva

Rabbit corneas

Admet, $50 \mathrm{~V}_{\mathrm{pp}}, \quad \mu$-EME- serum

$\mu \mathrm{M}$

serum

$0.32 \mu \mathrm{M}$ [56]

Plant

n.r.

0.49

$\mathrm{mg} / \mathrm{L}$

Honey, $\quad 0.44-$

shampoo, $\quad 3.83 \mu \mathrm{M}$

ap water

$0.8-2.9$ [82]

breath $\mu \mathrm{M}$

condensate

Exhaled $\quad 0.04-$

$0.37 \mu \mathrm{M}$

$0.5-1.3 \quad[82]$

condensate

Sweat, skin $\quad 2.3-4.2 \quad$ [87]

$\quad \mu \mathrm{M}$

0.5

condensate

Saliva $\quad 1.6-10$

$\mu \mathrm{M}$

0.02 ,

media $\quad 0.03 \mu \mathrm{M}$

$0.52-$

4.2

$\mathrm{mg} / \mathrm{L}$;

$10-84$

$\mu \mathrm{g} / \mathrm{L}$

(LLE)

$1-2.5$

$\mathrm{ng} / \mathrm{mL}$

n.r.

0.015

$\mathrm{mg} / \mathrm{kg}$

$0.03 \mu \mathrm{M}$ [75]

n.r.

$1.4-7$ $\mathrm{ng} / \mathrm{mL}$

0.4, 4

$\mathrm{mg} / \mathrm{L}$

Urine $\quad 0.75-$ 
CZE

1.5

$\mathrm{SCN}^{-}, \mathrm{NO}_{2}^{-}, \mathrm{NO}_{3}^{-} \quad 10 \mathrm{mM}$ His, $90 \mathrm{mM}$ acetic acid,

$80 \mathrm{~V}_{\mathrm{pp}}, 450 \mathrm{kHz}$

FASI-CZE

$\mathrm{mg} / \mathrm{L}$

pH 3.7

Serine (D,L

$3.2 \mathrm{mM} \mathrm{NaOH}, 0.4 \mathrm{mM}$ cit, $2.5 \quad$ n.r.

CZE

$3.1-4.9 \quad[84]$

forms)

$\mathrm{mM}$ copper acetate, $5 \mathrm{mM} \mathrm{Arg}$,

$15 \mathrm{mg} / \mathrm{L}$ HPMC, $\mathrm{pH} 9.8$

Shellfish toxins

$25 \mathrm{mM}$ sodium acetate adjusted

TraceDec, -12

to $\mathrm{pH} 4.2$ with acetic acid

$\mathrm{dB}, 150 \%$ gain

BGE/TE $500 \mathrm{mM}$ L-alanine, $\mathrm{pH}$ 3.5

TraceDec, -12

$\mathrm{dB}, 150 \%$ gain

Tamoxifen and

$7.5 \mathrm{mM}$ deoxycholic acid

eDAQ

sodium salt, $15 \mathrm{mM}$ acetic acid,

$1 \mathrm{mM}$ 18-crown-6 in 100\%

$\mathrm{MeOH}$

Valine,

$3.2 \mathrm{M}$ acetic acid in $20 \%(\mathrm{v} / \mathrm{v})$

isoleucine,

$\mathrm{MeOH}, \mathrm{pH} 2.0$

Admet, $50 \mathrm{~V}_{\mathrm{pp}}$, $1.84 \mathrm{MHz}$

Pressure-

assisted

$\mathrm{ng} / \mathrm{mL}$

Brain tissue 0.1

$\mathrm{mg} / \mathrm{L}$

CZE

Mussel

$140-$

715

$\mathrm{ng} / \mathrm{mL}$

tITP-CZE Mussel 74 -

1020

$\mathrm{ng} / \mathrm{mL}$

NACE Plasma 25-40

$\mathrm{ng} / \mathrm{mL}$

(LLE)

presence of other

CZE

Plasma

$0.4 \mu \mathrm{M}$

[74] amino acids

Environmental analysis

\begin{tabular}{|c|c|c|c|c|c|c|}
\hline Amino acids & $2 \mathrm{M}$ acetic acid & n.r. & $\begin{array}{l}\text { Portable } \\
\text { CZE }\end{array}$ & $\begin{array}{l}\text { Soil } \\
\text { samples }\end{array}$ & $\begin{array}{l}0.2- \\
0.61 \\
\mathrm{mg} / \mathrm{L}\end{array}$ & {$[55]$} \\
\hline As(III) & $\begin{array}{l}12 \text { mM MES, } 21 \text { mM Arg, } 35 \\
\mu \text { С CТAB, pH } 8.9\end{array}$ & $200 \mathrm{~V}_{\mathrm{pp}}, 400 \mathrm{kHz}$ & $\begin{array}{l}\text { Portable } \\
\text { CZE }\end{array}$ & $\begin{array}{l}\text { Water } \\
\text { samples }\end{array}$ & $5 \mu \mathrm{g} / \mathrm{L}$ & {$[52]$} \\
\hline Bromate & $300 \mathrm{mM}$ acetic acid & $90 \mathrm{~V}_{\mathrm{pp}}, 400 \mathrm{kHz}$ & EME-CZE & $\begin{array}{l}\text { Water } \\
\text { samples }\end{array}$ & $\begin{array}{l}0.12 \\
\mathrm{ng} / \mathrm{mL}\end{array}$ & {$[103]$} \\
\hline Haloacetic acids & $200 \mathrm{mM}$ acetic acid & $80 \mathrm{~V}_{\mathrm{pp}}, 500 \mathrm{kHz}$ & EME-CZE & $\begin{array}{l}\text { Water } \\
\text { samples }\end{array}$ & $\begin{array}{l}0.17- \\
0.61 \\
\mathrm{ng} / \mathrm{mL}\end{array}$ & {$[102]$} \\
\hline \multirow[t]{2}{*}{ Inorganic anions } & $\begin{array}{l}12 \mathrm{mM} \text { His, adjusted to } \mathrm{pH} 4 \\
\text { with acetic acid }\end{array}$ & $200 \mathrm{~V}_{\mathrm{pp}}, 400 \mathrm{kHz}$ & $\begin{array}{l}\text { Portable } \\
\text { CZE }\end{array}$ & $\begin{array}{l}\text { Water } \\
\text { samples }\end{array}$ & $\begin{array}{l}2.5-4.5 \\
\mu \mathrm{M}\end{array}$ & {$[52]$} \\
\hline & $\begin{array}{l}12 \mathrm{mM} \text { His, } 2 \mathrm{mM} \text { 18-crown- } 6 \\
\text { adjusted to } \mathrm{pH} 4 \text { with acetic acid }\end{array}$ & $200 \mathrm{~V}_{\mathrm{pp}}, 400 \mathrm{kHz}$ & $\begin{array}{l}\text { Automated } \\
\text { flow CZE }\end{array}$ & $\begin{array}{l}\text { Water } \\
\text { samples }\end{array}$ & $\begin{array}{l}6-7.5 \\
\mu \mathrm{M}\end{array}$ & {$[61]$} \\
\hline \multirow[t]{3}{*}{ Inorganic cations } & $\begin{array}{l}12 \mathrm{mM} \text { His, } 2 \mathrm{mM} 18 \text {-crown- } 6 \\
\text { adjusted to } \mathrm{pH} 3.7 \text { with acetic } \\
\text { acid }\end{array}$ & $200 \mathrm{~V}_{\mathrm{pp}}, 400 \mathrm{kHz}$ & $\begin{array}{l}\text { Portable } \\
\text { CZE }\end{array}$ & $\begin{array}{l}\text { Water } \\
\text { samples }\end{array}$ & $\begin{array}{l}4.5-10 \\
\mu \mathrm{M}\end{array}$ & {$[52]$} \\
\hline & $\begin{array}{l}12 \mathrm{mM} \text { His, } 2 \mathrm{mM} \text { 18-crown- } 6 \\
\text { adjusted to } \mathrm{pH} 4 \text { with acetic acid }\end{array}$ & $200 \mathrm{~V}_{\mathrm{pp}}, 400 \mathrm{kHz}$ & $\begin{array}{l}\text { Automated } \\
\text { flow CZE }\end{array}$ & $\begin{array}{l}\text { Water } \\
\text { samples }\end{array}$ & $5 \mu \mathrm{M}$ & {$[61]$} \\
\hline & $\begin{array}{l}30 \mathrm{mM} \text { MES, } 30 \mathrm{mM} \text { His, } 2 \mathrm{mM} \\
18 \text {-crown- } 6 \text {, pH } 6.0\end{array}$ & $380 \mathrm{~V}_{\mathrm{pp}}, 200 \mathrm{kHz}$ & $\mathrm{CZE}$ & $\begin{array}{l}\text { Water } \\
\text { samples, } \\
\text { sediments }\end{array}$ & $10 \mu \mathrm{M}$ & {$[63]$} \\
\hline $\begin{array}{l}\text { Perchlorate in } \\
\text { presence of } \mathrm{Cl}^{-} \\
\mathrm{NO}_{3}^{-}, \mathrm{SO}_{4}^{2-}\end{array}$ & $10 \%(\mathrm{v} / \mathrm{v})$ acetic acid & $\begin{array}{l}\text { Admet, } 50 \mathrm{~V}_{\mathrm{pp}} \\
1.84 \mathrm{MHz}\end{array}$ & $\begin{array}{l}\mu-E M E- \\
\mathrm{CZE}\end{array}$ & $\begin{array}{l}\text { Water } \\
\text { samples }\end{array}$ & n.r. & {$[101]$} \\
\hline Phosphate & $\begin{array}{l}1 \mathrm{mM} \text { His, adjusted to } \mathrm{pH} 3.5 \\
\text { with acetic acid }\end{array}$ & $200 \mathrm{~V}_{\mathrm{pp}}, 400 \mathrm{kHz}$ & $\begin{array}{l}\text { Portable } \\
\text { CZE }\end{array}$ & $\begin{array}{l}\text { Water } \\
\text { samples }\end{array}$ & $5 \mu \mathrm{M}$ & {$[52]$} \\
\hline $\begin{array}{l}\text { Tetrakis(hydroxy } \\
\text { methyl)phosphoni } \\
\text { um sulfate }\end{array}$ & $20 \mathrm{mM}$ sodium borate, $\mathrm{pH} 9.2$ & $1.5 \mathrm{~V}_{\mathrm{pp}}, 620 \mathrm{kHz}$ & $\mathrm{CZE}$ & $\begin{array}{l}\text { Cooling } \\
\text { water, } \\
\text { powdered } \\
\text { biocide }\end{array}$ & $15 \mu \mathrm{M}$ & {$[104]$} \\
\hline
\end{tabular}

Industrial applications

Inorganic anions $60 \mathrm{mM}$ MES, $60 \mathrm{mM}$ His, $2 \mathrm{mM}$ eDAQ, $\quad$ Portable $\quad$ Fireworks $\quad 2-3$ 
18-crown-6, pH 6.0

amplitude 100\%, CZE

$1200 \mathrm{kHz}$

Inorganic anions

$500 \mathrm{mM}$ acetic acid, $20 \mathrm{mM}$

$18 \mathrm{~V}_{\mathrm{pp}}, 320 \mathrm{kHz} \quad$ SI-CZE

and cations

Tris, 2 mM 18-crown-6, pH 3.3

Inorganic cations

$30 \mathrm{mM}$ His, $30 \mathrm{mM}$ lactic acid,

4 mM 18-crown-6, pH 4.9

$\mathrm{HV}-\mathrm{C}^{4} \mathrm{D}, \mathrm{eDAQ}$

$60 \mathrm{mM}$ MES, $60 \mathrm{mM}$ His, $2 \mathrm{mM}$

Inorganic cations

18-crown-6, pH 6.0

eDAQ,

Breadbord

CZE

and $\mathrm{Cu}^{2+}$

amplitude $100 \%$, CZE

$\mathrm{K}^{+}, \mathrm{NH}_{4}^{+}$

$500 \mathrm{mM}$ acetic acid, $20 \mathrm{mM}$

Tris, 2 mM 18-crown-6, pH 3.3

$1200 \mathrm{kHz}$

$17 \mathrm{~V}_{\mathrm{pp}}, 450 \mathrm{kHz} \quad$ SI-CZE

fertilizer

Liquid

$\mu \mathrm{M}$

$\begin{array}{lll}\text { Liquid } & 6.9- & {[60]} \\ \text { fertilizer } & 10.6 \mu \mathrm{M} & \\ \text { Himalayan } & 2-7 & \text { [62] } \\ \text { rock salt } & \mu \mathrm{M} & \\ \text { Fireworks } & 1-5 & \text { [53] } \\ & \mu \mathrm{M} & \\ & & \end{array}$

Standard solutions

Acetate, L-

ascorbate,

phosphate

Amino acids
$25 \mathrm{mM}$ MES, $25 \mathrm{mM}$ His, 150

$\mu \mathrm{M}$ CTAB, $\mathrm{pH} 6.0$

LE: imidazole in $80 \%(\mathrm{v} / \mathrm{v})$

DMSO, TE: taurine in $80 \%(\mathrm{v} / \mathrm{v})$

DMSO, CZE BGE: $20 \mathrm{mM}$

oxalic acid in $20 \%(\mathrm{v} / \mathrm{v}) 2$ -

propanol

LE: $10 \mathrm{mM}$ potassium acetate,

$52.3 \mathrm{mM}$ acetic acid, $\mathrm{pH} 4.0$

TE: $10 \mathrm{mM}$ alanine

Caffeic, gallic,

chlorogenic acid

$\mathrm{Cl}^{-}, \mathrm{ClO}_{4}^{-}$

$\mathrm{Cu}^{2+}$

Cu-EDTA,

EDTA, acid

orange II

$\mathrm{Cu}$-EDTA,

EDTA, $\mathrm{Cl}^{-}$,

oxalate,

glyoxylate,

formate,

iminodiacetate

Inorganic anions

$25 \mathrm{mM}$ borate buffer, $\mathrm{pH} 9.35$

$16.5 \%(\mathrm{v} / \mathrm{v})$ acetic acid

$60 \mathrm{mM}$ acetic acid

$20 \mathrm{mM}$ acetic acid

$20 \mathrm{mM}$ acetic acid

$12 \mathrm{mM}$ His adjusted to $\mathrm{pH} 4$

with acetic acid

$12 \mathrm{mM}$ His, $0.5-1 \%$ sodium acetate adjusted to $\mathrm{pH} 4$ with acetic acid

n.r.

$30 \mathrm{mM}$ His, $30 \mathrm{mM}$ lactic acid,

4 mM 18-crown-6, pH 4.9

Inorganic cations $10 \mathrm{mM}$ His, $50 \mathrm{mM}$ acetic acid,

0.5 mM 18-crown-6

$\mathrm{K}^{+}, \mathrm{Na}^{+}$

$20 \mathrm{mM}$ MES, $20 \mathrm{mM}$ His, $\mathrm{pH}$

6.1

$\mathrm{K}^{+}, \mathrm{Na}^{+}, \mathrm{Ca}^{2+}$,

His

$\mathrm{K}^{+}, \mathrm{Na}^{+}$, Tris
$100 \mathrm{mM}$ L-ascorbic acid, $\mathrm{pH}$

2.56

$20 \mathrm{mM}$ MES, $20 \mathrm{mM}$ His

$\begin{array}{llll}\begin{array}{l}\text { AD7745, } 5 \mathrm{~V}_{\mathrm{pp}}, \\ 32 \mathrm{kHz}\end{array} & \text { CZE } & \begin{array}{l}\text { Standard } \\ \text { solutions }\end{array} & \begin{array}{l}0.4-1 . \\ \mu \mathrm{M}\end{array} \\ \text { CSense One } & \begin{array}{l}\text { NAITP- } \\ \text { CZE }\end{array} & \begin{array}{l}\text { Standard } \\ \text { solutions }\end{array} & \text { n.r. }\end{array}$

[31]

[140]

HV-C ${ }^{4}$, eDAQ Breadbord Standard

n.r.

[62]

solutions

AD7745, $5 \mathrm{~V}_{\mathrm{pp}}, \quad \mathrm{CZE} \quad$ Standard

$60 \mu \mathrm{M}$

[31]

$32 \mathrm{kHz}$

solutions

Admet, $50 \mathrm{~V}_{\mathrm{pp}}, \quad \mu$-EME- $\quad$ Standard

$1.84 \mathrm{MHz} \quad \mathrm{CZE} \quad$ solutions

n.r. $\quad \mathrm{CZE}$

Standard

solutions

n.r.

CZE

Standard

solutions

n.r.

$0.03 \mu \mathrm{M} \quad[107]$

n.r.

Standard

$0.16-$

n.r. $\quad \mathrm{CZE}$

solutions

$2.1 \mu \mathrm{M}$

$22 \mathrm{~V}_{\mathrm{pp}}, 1 \mathrm{kHz}$

Low-bore

Standard

n.r.

CZE,

portable

$\mathrm{C}^{4} \mathrm{D}$

$22 \mathrm{~V}_{\mathrm{pp}}, 12.3 \mathrm{kHz} \quad$ Low-bore

CZE, portable

$\mathrm{C}^{4} \mathrm{D}$
HV-C ${ }^{4}$ D, eDAQ Breadbord Standard GEMBE

solutions

HV-C ${ }^{4} \mathrm{D}, \mathrm{eDAQ}$

Breadbord

Standard

solutions

Admet, $50 \mathrm{~V}_{\mathrm{pp}}$, EME-CZE

Standard

solutions

Standard

solutions

Standard

solutions

Standard

n.r.

n.r.

$\mathrm{AD} 7745,5 \mathrm{~V}_{\mathrm{pp}}, \quad \mathrm{CZE}$

$\mathrm{AD} 7745,5 \mathrm{~V}_{\mathrm{pp}}, \quad \mathrm{CZE}$

$32 \mathrm{kHz}$

$\mathrm{AD} 7745,3.3 \mathrm{~V}_{\mathrm{pp}}$, CZE, n.r.

n.r.

$1-1.4$

$\mu \mathrm{M}$

$0.25-$
[20] 


\begin{tabular}{|c|c|c|c|c|c|c|}
\hline & & $32 \mathrm{kHz}$ & $\begin{array}{l}\text { portable } \\
\mathrm{C}^{4} \mathrm{D}\end{array}$ & solutions & $\begin{array}{l}0.8 \mu \mathrm{M} \\
(\mathrm{LOQs})\end{array}$ & \\
\hline $\mathrm{K}^{+}, \mathrm{NH}_{4}^{+}$ & $16.5 \%(\mathrm{v} / \mathrm{v})$ acetic acid & $\begin{array}{l}\text { Admet, } 50 \mathrm{~V}_{\mathrm{pp}} \\
1.84 \mathrm{MHz}\end{array}$ & $\begin{array}{l}\mu \text {-EME- } \\
\text { CZE }\end{array}$ & $\begin{array}{l}\text { Standard } \\
\text { solutions }\end{array}$ & n.r. & [81] \\
\hline \multirow[t]{2}{*}{ Mixed micelles } & $5-40 \mathrm{mM}$ sodium tetraborate & $20 \mathrm{~V}_{\mathrm{pp}}, 120 \mathrm{kHz}$ & CZE & $\begin{array}{l}\text { Standard } \\
\text { solutions }\end{array}$ & n.r. & [134] \\
\hline & $5-40 \mathrm{mM}$ sodium tetraborate & $20 \mathrm{~V}_{\mathrm{pp}}, 120 \mathrm{kHz}$ & CZE & $\begin{array}{l}\text { Standard } \\
\text { solutions }\end{array}$ & n.r. & [133] \\
\hline \multirow[t]{2}{*}{ Organic anions } & $\begin{array}{l}12 \text { mM HIBA, } 10 \mathrm{mM} \mathrm{NaOH} \text {, } \\
\text { pH } 4.67\end{array}$ & $\begin{array}{l}\text { TraceDec, HV- } \\
\mathrm{C}^{4} \mathrm{D} \text {, n.r. }\end{array}$ & $\begin{array}{l}\text { Computer } \\
\text { simulations }\end{array}$ & $\begin{array}{l}\text { Standard } \\
\text { solutions }\end{array}$ & n.r. & {$[66]$} \\
\hline & $\begin{array}{l}50 \mathrm{mM} \text { Tris, } 50 \mathrm{mM} \text { MOPS, } \mathrm{pH} \\
7.6\end{array}$ & $380 \mathrm{~V}_{\mathrm{pp}}, 200 \mathrm{kHz}$ & CZE & $\begin{array}{l}\text { Standard } \\
\text { solutions }\end{array}$ & n.r. & [105] \\
\hline \multirow[t]{2}{*}{$\begin{array}{l}\text { Organic anions, } \\
\text { arginine, } \\
\text { tryptamine }\end{array}$} & $\begin{array}{l}20 \mathrm{mM} \text { formic acid, } 10 \mathrm{mM} \\
\mathrm{NaOH} \\
10 \mathrm{mM} \text { formic acid, } 5 \mathrm{mM} \\
\mathrm{NaOH}\end{array}$ & $20 V_{p p}$, f: n.r. & CZE & $\begin{array}{l}\text { Standard } \\
\text { solutions }\end{array}$ & n.r. & [65] \\
\hline & $\begin{array}{l}\text { LE: } 10 \mathrm{mM} \mathrm{NaOH}, 24.6 \mathrm{mM} \\
\text { acetic acid } \\
\text { TE: } 10 \mathrm{mM} \text { acetic acid }\end{array}$ & $20 V_{p p}$, f: n.r. & ITP & $\begin{array}{l}\text { Standard } \\
\text { solutions }\end{array}$ & n.r. & {$[65]$} \\
\hline Phenols & $\begin{array}{l}10 \mathrm{mM} \text { ammonium acetate } \\
\text { adjusted to } \mathrm{pH} 9.0 \text { with } \\
\text { ammonia }\end{array}$ & $4 \mathrm{~V}_{\mathrm{pp}}, 1.1 \mathrm{MHz}$ & CZE & $\begin{array}{l}\text { Standard } \\
\text { solutions }\end{array}$ & $\begin{array}{l}3.1-75 \\
\mu \mathrm{M}\end{array}$ & [142] \\
\hline $\begin{array}{l}\text { Proteins } \\
\text { (lysozyme, } \\
\text { trypsin inhibitor) }\end{array}$ & $\begin{array}{l}\text { Phosphate buffer, } \mathrm{pH} \\
6.9 / \text { tetrahydrofuran } 90 / 10(\mathrm{v} / \mathrm{v})\end{array}$ & $380 \mathrm{~V}_{\mathrm{pp}}, 200 \mathrm{kHz}$ & CZE & $\begin{array}{l}\text { Standard } \\
\text { solutions }\end{array}$ & n.r. & [105] \\
\hline \multirow[t]{2}{*}{ S-nitrosothiols } & $\begin{array}{l}20 \mathrm{mM} \text { CHES adjusted to } \mathrm{pH} 10 \\
\text { with } \mathrm{NaOH}\end{array}$ & $1.9 \mathrm{~V}_{\mathrm{pp}}, 600 \mathrm{kHz}$ & CZE & $\begin{array}{l}\text { Standard } \\
\text { solutions }\end{array}$ & $\begin{array}{l}6-15 \\
\mu \mathrm{M}\end{array}$ & [108] \\
\hline & $\begin{array}{l}20 \mathrm{mM} \text { CHES, } 116 \mu \mathrm{M} \text { DDAB, } \\
\text { adjusted to } \mathrm{pH} 9 \text { with } \mathrm{NaOH}\end{array}$ & $1.9 \mathrm{~V}_{\mathrm{pp}}, 600 \mathrm{kHz}$ & CZE & $\begin{array}{l}\text { Standard } \\
\text { solutions }\end{array}$ & $\begin{array}{l}6-15 \\
\mu \mathrm{M}\end{array}$ & [108] \\
\hline $\begin{array}{l}\text { Total protein } \\
\text { assay }\end{array}$ & $25 \mathrm{mM}$ carbonate buffer, $\mathrm{pH} 9.4$ & TraceDec & GEMBE & $\begin{array}{l}\text { Standard } \\
\text { solutions }\end{array}$ & $\begin{array}{l}0.4-2 \\
\mu \mathrm{g} / \mathrm{mL}\end{array}$ & [109] \\
\hline
\end{tabular}

$\mathrm{ACN}$ - acetonitrile

Arg - L-arginine

Brij 35 - polyoxyethylene 23 lauryl ether

CTAB - cetyl trimethylammonium bromide

DDAB - dihexadecyl dimethyl ammonium bromide

DMSO - dimethylsulfoxide

DOI - dual opposite end injection

EME - electromembrane extraction

FASI - field amplified sample injection

FI - sequential injection

GEMBE - gradient elution moving boundary electrophoresis

HIBA - $\alpha$-hydroxyisobutyric acid

His - L-histidine

HPMC - hydroxypropyl methylcellulose

CHES - 2-(cyclohexylamino) ethanesulfonic acid

LLE - liquid-liquid extraction

LVSS - large volume sample stacking

MA - methamphetamine

mCPP - meta-chlorophenylpiperazine

MDA - 3,4-methylenedioxy amphetamine

MDEA - 3,4-methylenedioxy- $N$-ethylamphetamine

MDMA - 3,4-methylenedioxy- $N$-methylamphetamine 


\author{
$\mathrm{MeOH}$ - methanol \\ MES - 2-(N-morpholino)-ethanesulfonic acid \\ $\mu$-EME - micro-electromembrane extraction \\ MOPS - 3-( $N$-morpholino)-propanesulfonic acid \\ NACE - non-aqueous capillary electrophoresis \\ NAITP - non-aqueous isotachophoresis \\ PIM - polymer inclusion membrane \\ SI - sequential injection \\ TAPS - N-tris(hydroxymethyl)methyl-3-aminopropanesulfonic acid \\ tITP - transient isotachophoresis \\ Tris - tris(hydroxymethyl)aminomethane \\ Tween 20 - Polyethylene glycol sorbitan monolaurate \\ n.r. - not reported
}


Table 2. Applications of $C^{4} \mathrm{D}$ in microchip electrophoresis.

\begin{tabular}{|c|c|c|c|c|c|c|c|}
\hline Analytes & BGE composition & $\begin{array}{l}\mathrm{C}^{4} \mathrm{D} \\
\text { parameters }\end{array}$ & Material & Mode & Sample type & LODs & Ref. \\
\hline Histamine & $\begin{array}{l}5 \mathrm{mM} \text { His, } 50 \mathrm{mM} \\
\mathrm{HEPES}, 5 \%(\mathrm{v} / \mathrm{v}) \\
\text { isopropanol, } \mathrm{pH} 6.03\end{array}$ & $\begin{array}{l}10 \mathrm{~V}_{\mathrm{pp}}, 216 \\
\mathrm{kHz}\end{array}$ & PDMS & CZE & Fish samples & $\begin{array}{l}0.43 \\
\mathrm{mg} / \mathrm{L}\end{array}$ & [115] \\
\hline $\begin{array}{l}\text { Inorganic and } \\
\text { organic anions }\end{array}$ & $\begin{array}{l}50 \mathrm{mM} \text { MES, } 50 \mathrm{mM} \\
\text { His, pH } 6.0\end{array}$ & eDAQ ET121 & PDMS & CZE & $\begin{array}{l}\text { Water } \\
\text { samples, } \\
\text { saliva, } \\
\text { toothpaste }\end{array}$ & $\begin{array}{l}3.7- \\
14.7 \mu \mathrm{M}\end{array}$ & [113] \\
\hline Inorganic anions & $\begin{array}{l}30 \mathrm{mM} \text { lactic acid, } 15 \\
\mathrm{mM} \text { His }\end{array}$ & $\begin{array}{l}60 \mathrm{~V}_{\mathrm{pp}}, 1100 \\
\mathrm{kHz}\end{array}$ & Glass & CZE & $\begin{array}{l}\text { Environmental } \\
\text { samples }\end{array}$ & $\begin{array}{l}2.0-4.9 \\
\mu \mathrm{M}\end{array}$ & [114] \\
\hline $\mathrm{K}^{+}, \mathrm{Na}^{+}, \mathrm{Li}^{+}$ & $\begin{array}{l}10 \mathrm{mM} \text { MES, } 10 \mathrm{mM} \\
\text { His }\end{array}$ & $\begin{array}{l}160 \mathrm{~V}_{\mathrm{pp}}, 60 \\
\mathrm{kHz}\end{array}$ & PDMS/PET & CZE & River water & $\begin{array}{l}4.8- \\
14.3 \mu \mathrm{M}\end{array}$ & {$[42]$} \\
\hline $\mathrm{K}^{+}, \mathrm{Na}^{+}, \mathrm{Li}^{+}$ & $\begin{array}{l}20 \mathrm{mM} \text { MES, } 20 \mathrm{mM} \\
\text { His, } \mathrm{pH} 6.1\end{array}$ & $4 \mathrm{~V}_{\mathrm{pp}}, 420 \mathrm{kHz}$ & PDMS & CZE & $\begin{array}{l}\text { Standard } \\
\text { solutions }\end{array}$ & n.r. & [117] \\
\hline $\mathrm{K}^{+}, \mathrm{Na}^{+}, \mathrm{Li}^{+}$ & $\begin{array}{l}20 \mathrm{mM} \text { MES, } 20 \mathrm{mM} \\
\text { His, pH } 6.1\end{array}$ & $3 \mathrm{~V}_{\mathrm{pp}}, 300 \mathrm{kHz}$ & PMMA & CZE & $\begin{array}{l}\text { Standards, tear } \\
\text { samples }\end{array}$ & $\begin{array}{l}4.9-9 \\
\mu \mathrm{M}\end{array}$ & {$[43]$} \\
\hline $\mathrm{K}^{+}, \mathrm{Na}^{+}, \mathrm{Li}^{+}$ & $\begin{array}{l}20 \mathrm{mM} \text { MES, } 20 \mathrm{mM} \\
\text { His, } \mathrm{pH} 6.0\end{array}$ & $\begin{array}{l}1.1 \mathrm{~V}_{\mathrm{pp}}, 500 \\
\mathrm{kHz}\end{array}$ & PDMS & CZE & $\begin{array}{l}\text { Standard } \\
\text { solutions }\end{array}$ & n.r. & [96] \\
\hline $\mathrm{K}^{+}, \mathrm{Na}^{+}, \mathrm{Li}^{+}$ & $\begin{array}{l}20 \mathrm{mM} \text { MES, } 20 \mathrm{mM} \\
\text { His }\end{array}$ & $2 \mathrm{~V}_{\mathrm{pp}}, 400 \mathrm{kHz}$ & PDMS & $\mathrm{CZE}$ & $\begin{array}{l}\text { Standard } \\
\text { solutions }\end{array}$ & $\begin{array}{l}28-58 \\
\mu \mathrm{M}\end{array}$ & {$[45]$} \\
\hline $\mathrm{Na}^{+}$ & $\begin{array}{l}10 \mathrm{mM} \text { MES, } 10 \mathrm{mM} \\
\text { His, pH } 5.9\end{array}$ & n.r. & PDMS & CZE & $\begin{array}{l}\text { Standard } \\
\text { solutions }\end{array}$ & n.r. & [118] \\
\hline $\mathrm{Zn}^{2+}, \mathrm{Cd}^{2+}, \mathrm{Cu}^{2+}$ & $\begin{array}{l}100 \mathrm{mM} \text { acetic acid, } \\
\mathrm{pH} 4.0\end{array}$ & $\begin{array}{l}160 \mathrm{~V}_{\mathrm{pp}}, 60 \\
\mathrm{kHz}\end{array}$ & PDMS/PET & CZE & River water & n.r. & {$[42]$} \\
\hline
\end{tabular}

HEPES - 2-[4-(2-hydroxyethyl)piperazin-1-yl]ethanesulfonic acid PDMS - poly(dimethylsiloxane) PMMA - poly(methylmethacrylate) PET - poly(ethylene terephthalate) n.r. - not reported 
Table 3. Other analytical applications of $\mathrm{C}^{4} \mathrm{D}$.

\begin{tabular}{|c|c|c|c|c|}
\hline Application & Analytes/Procedures & $\mathrm{C}^{4} \mathrm{D}$ parameters & LODs & Ref. \\
\hline $\begin{array}{l}\text { Capillary } \\
\text { electrokinetic } \\
\text { fractionation }\end{array}$ & $\begin{array}{l}\text { Monitoring of capillary filling and } \\
\text { separation }\end{array}$ & TraceDec & n.r. & {$[125]$} \\
\hline \multirow[t]{3}{*}{ Capillary HPLC } & Column characterization & TraceDec & n.r. & {$[123]$} \\
\hline & Column characterization & TraceDec & n.r. & {$[124]$} \\
\hline & Column conductivity measurements & TraceDec & n.r. & {$[126]$} \\
\hline \multirow[t]{3}{*}{ Capillary IC } & Column characterization & TraceDec & n.r. & {$[120]$} \\
\hline & $\mathrm{Mg}^{2+}, \mathrm{Ba}^{2+}$ & $\begin{array}{l}\text { TraceDec, f: } 2 \text { x HIGH; } \\
\text { V: }-12 \mathrm{~dB} \text {; gain: } 50 \%\end{array}$ & n.r. & {$[120]$} \\
\hline & $\mathrm{Li}^{+}, \mathrm{Na}^{+}, \mathrm{NH}_{4}^{+}, \mathrm{K}^{+}, \mathrm{Rb}^{+}, \mathrm{Cs}^{+}$ & TraceDec & $0.1-0.8 \mathrm{mM}$ & {$[119]$} \\
\hline \multirow{6}{*}{$\begin{array}{l}\text { Flow-through } \\
\text { methods }\end{array}$} & Two-phase flow measurements & V n.r., 200-300 kHz & n.r. & {$[130]$} \\
\hline & Two-phase flow measurements & n.r. & n.r. & {$[129]$} \\
\hline & $\begin{array}{l}\text { Two-phase system conductivity } \\
\text { measurements }\end{array}$ & eDAQ ER125 & n.r. & {$[132]$} \\
\hline & $\begin{array}{l}\text { Conductivity measurements in large ID } \\
\text { tubes }\end{array}$ & V n.r., $135-165 \mathrm{kHz}$ & n.r. & [39] \\
\hline & $\begin{array}{l}\text { Conductivity measurements in large ID } \\
\text { tubes }\end{array}$ & V n.r., $171-200 \mathrm{kHz}$ & n.r. & {$[37]$} \\
\hline & Methanol/ethanol in aqueous samples & Admet, $50 \mathrm{~V}_{\mathrm{pp}}, 1 \mathrm{MHz}$ & n.r. & {$[135]$} \\
\hline Microfluidics & $\begin{array}{l}\text { Conductivity measurements during } \\
\text { acid/hydroxide mixing }\end{array}$ & $\begin{array}{l}\text { http://sites.google.com/ } \\
\text { site/openC4D/ }\end{array}$ & n.r. & {$[40]$} \\
\hline $\mathrm{LC}$ & $\begin{array}{l}\text { Aminoglycosidic antibiotics } \\
\text { Amino acids }\end{array}$ & $\begin{array}{l}40-50 \mathrm{~V}_{\mathrm{pp}}, 250-800 \\
\mathrm{kHz} \text {; eDAQ EA120: } \\
\text { amplitude } 100 \%, 1200 \\
\mathrm{kHz}\end{array}$ & n.r. & {$[121]$} \\
\hline \multirow[t]{2}{*}{ Open-tubular IC } & Inorganic anions & $22 \mathrm{~V}_{\mathrm{pp}}, 1 \mathrm{kHz}$ & $\leq 1 \mu \mathrm{M}$ & {$[21]$} \\
\hline & Inorganic anions & $22 \mathrm{~V}_{\mathrm{pp}}, 500 \mathrm{~Hz}$ & $\mathrm{Br}^{-}: 27 \mathrm{nM}$ & {$[20]$} \\
\hline Portable IC & Inorganic anions & AD7746, $32 \mathrm{kHz}$ & $\begin{array}{l}0.023-0.55 \\
\mathrm{mg} / \mathrm{L} ; 0.47-11 \\
\mu \mathrm{g} / \mathrm{L} \text { (large } \\
\text { sample loop) }\end{array}$ & [33] \\
\hline
\end{tabular}

HPLC - high performance liquid chromatogaphy

IC - ion chromatography

n.r. - not reported 


\section{Figure Captions}

Fig. 1 Illustration of the basic cell design of Zhang et al. (a) and the detailed equivalent circuit model required for modelling a high resistance cell (b). 1 - capillary, 2 grounded metal box, 3 - electrode, 4 - crimp-snap connector, 5 - BNC connector, 6 - grounded Faraday shield, 7 - adhesive paper tape for insulation. Reprinted with permission from [19]. Copyright (2014) American Chemical Society.

Fig. 2 CE separation of inorganic anions using admittance detector in 2 and $5 \mu \mathrm{m}$ ID fused silica capillaries. Reprinted with permission from [20]. Copyright (2014) American Chemical Society.

Fig. 3 (A) Photograph of a portable CE- $C^{4} \mathrm{D}$ according to [56], $\mathrm{T}-$ tablet, $\mathrm{HV}-$ high voltage electrode, $\mathrm{INJ}+\mathrm{G}$ - injection interface and ground electrode, $\mathrm{CP}$ - control panel, DAS - data acquisition system and (B) CE-C ${ }^{4}$ D determination of formate in serum of a patient after methanol intoxication (trace B). Reproduced with permission from Elsevier.

Fig. 4 CE-C ${ }^{4} \mathrm{D}$ determination of analgesic and antipyretic drugs in standard solutions reported in [73]. Abbreviations: DIP - dipyrone, SCO - scopolamine, COD codeine, ORP - orphenadrine, CAF - caffeine, MEP - mepyramine, AA - ascorbic acid. Reproduced with permission from Sociedade Brasileira de Química.

Fig. 5 CE-C ${ }^{4}$ D determination of selected haloacetic acids in potable water reported in [102]. Peak assignment: 1 - dichloroacetic acid, 2 - trichloroacetic acids, 3 - 
dibromoacetic acid, 4 - monochloroacetic acid, 5 - monobromoacetic acid.

Reproduced with permission from Wiley.

Fig. 6 MCE-C ${ }^{4} \mathrm{D}$ determination of anions in biofertilizer and environmental samples reported in [114]. Reproduced with permission from Elsevier.

Fig. 7 Repeatability of portable IC-C $\mathrm{C}^{4} \mathrm{D}$ over 14 days of continuous operation reported by Elkin [33]. Peak assignment: 1 - chloride, 2 - sulphate, 3 - nitrate, 4 - phosphate. Reproduced with permission from Elsevier. 
a
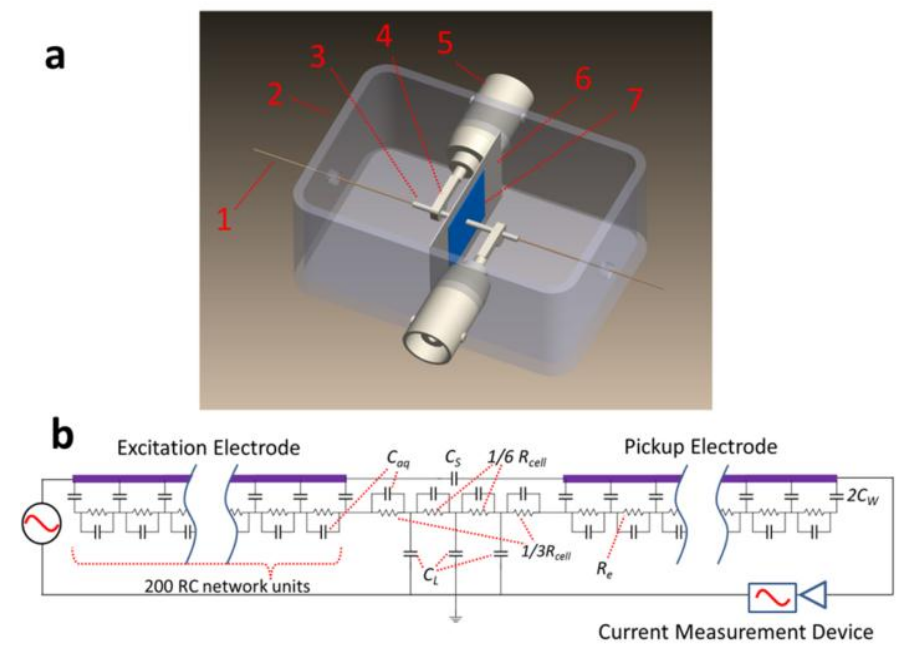

16

17

18

19

20

21

22

23

24

25

26

27

28

29

30

31

32

33

34

35

36

37

38

39

40

41

42

43

44

45

46

47

48

49

50

51

52

53

54

55

56

57

Figure 1 
1

2

3

4

5

6

7

8

9

10

11

12

13

14

15

16

17

18

19

20

21

22

23

24

25

26

27

28

29

30

31

32

33

34

35

36

37

38

39

40

41

42

43

44

45

46

47

48

49

50

51

52

53

54

55

56

57

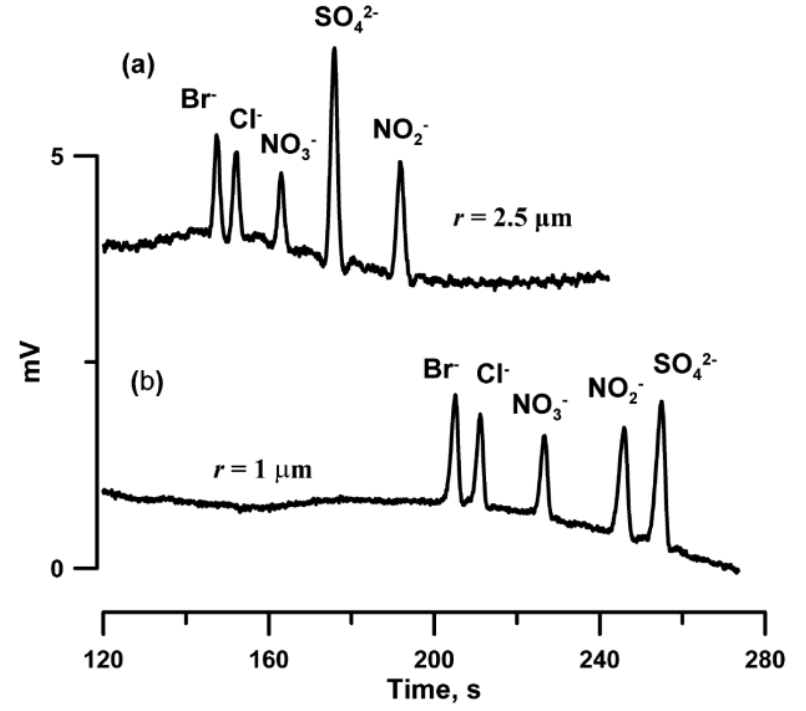

Figure 2 


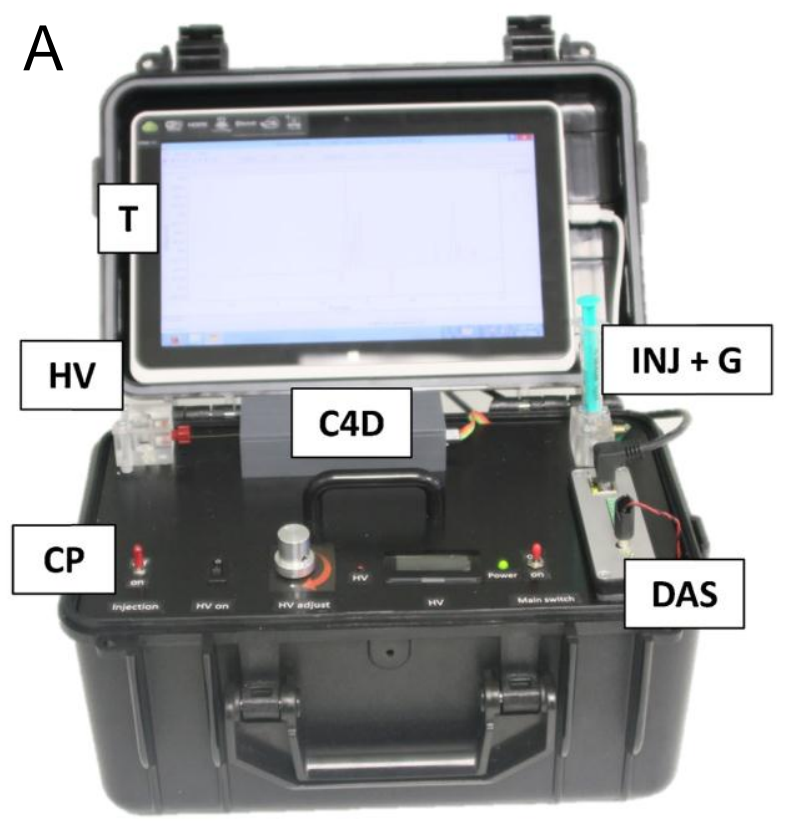

20

21

22

23

24

25

26

27

28

29

30

31

32

33

34

35

36

37

38

39

40

41

42

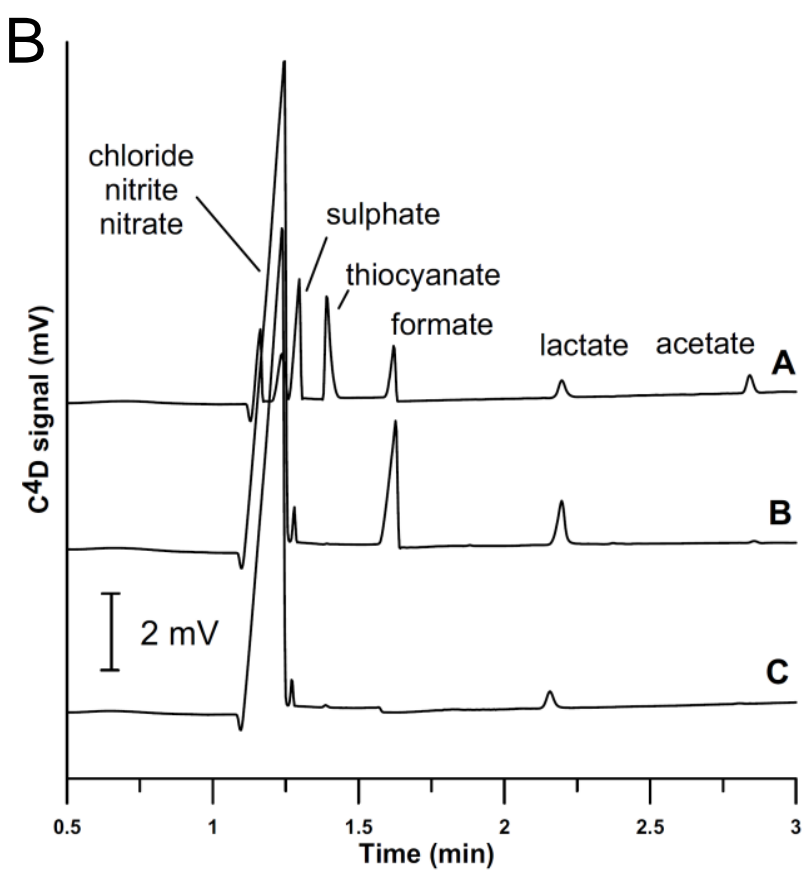

43

44

45

46

47

48

49

50

51

52

53

54

55

56

57 


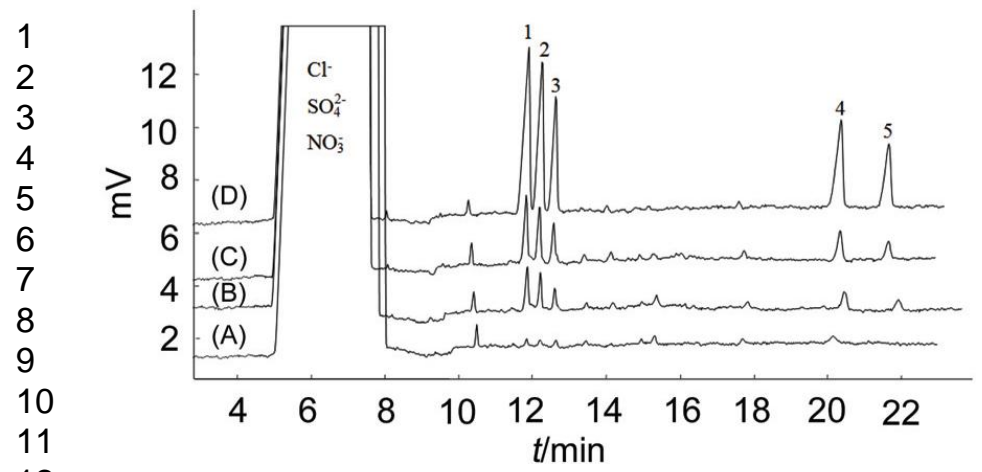




\section{Page 51 of 52}

1

2

3

4

5

6
7

7
8

9

10

11

12

13

14

15

16

17

18

19

20

21

22

23

24

25

26

27

28

29

30

31

32

33

34

35

36

37

38

39

40

41

42

43

44

45

46

47

48

49

50

51

52

53

54

55

56

57

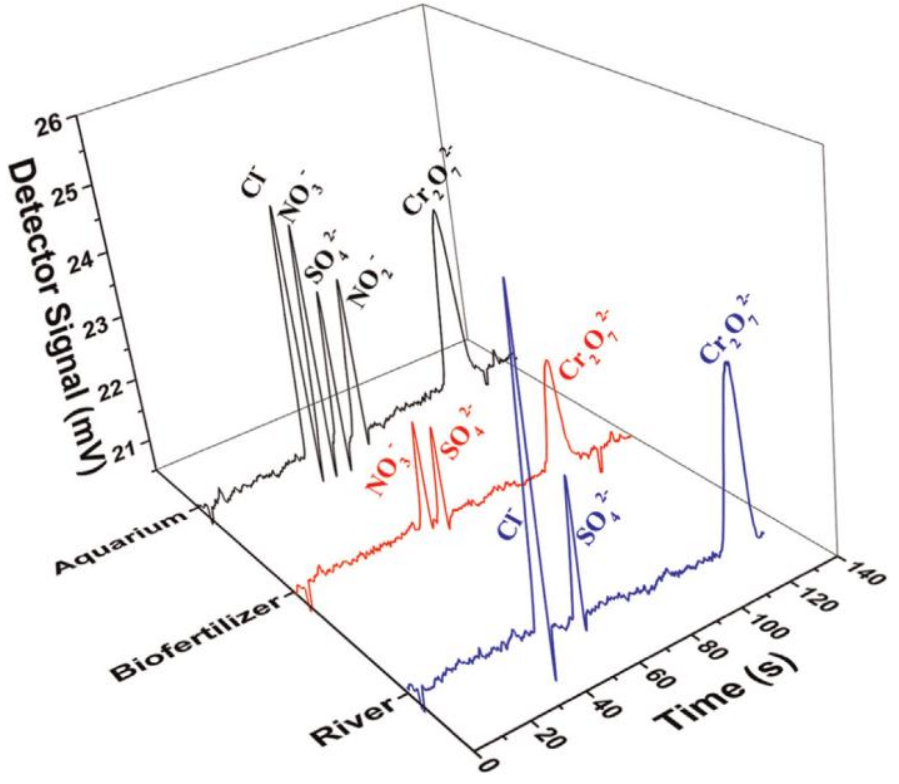

58

Figure 6 


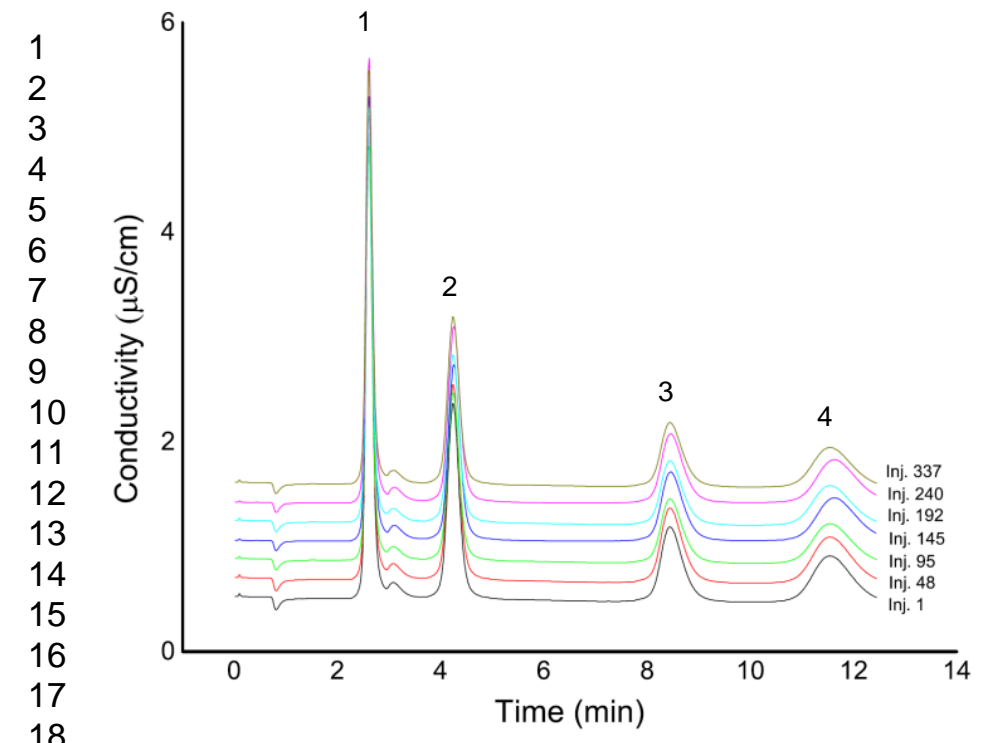

19

20

21

22

23

24

25

26

27

28

29

30

31

32

33

34

35

36

37

38

39

40

41

42

43

44

45

46

47

48

49

50

51

52

53

54

55

56

57

58

Figure 7 